\title{
SLIČNOSTI I RAZLIKE NAKNADE ŠTETE NASTALE PACIJENTIMA U ZDRAVSTVENOJ USTANOVI U REPUBLICI SLOVENIJI I REPUBLICI HRVATSKOJ (KROZ DVA SUDSKA PREDMETA)
}

Doc. dr. sc. Jakob Nakic**

Izv. prof. dr. sc. Loris Belanic***

\author{
UDK: 347.426.6:618.1 \\ https://doi.org/10.30925/zpfsr.40.1.17 \\ Ur.: 8. siječnja 2019. \\ Pr.: 29. siječnja 2019. \\ Pregledni znanstveni rad
}

\begin{abstract}
Sažetak
Autori u radu paralelno prikazuju zakonsku regulativu naknade imovinske i neimovinske štete nastale u zdravstvenim ustanovama u Republici Sloveniji $i$ Republici Hrvatskoj. Nadalje se analizira tko odgovara za štete nastale u zdravstvenim ustanovama i prema kojoj osnovi. Također se daje prikaz pravnog odnosa između pacijenata i zdravstvene ustanove, tj. liječnika. U sudskoj praksi u zadnje vrijeme uočava se povećanje zahtjeva za naknadu štete pacijenata prema zdravstvenim ustanovama, stoga se u radu prikazuju po jedan sudski predmet, povezan s naknadom štete nastalom u zdravstvenoj ustanovi, iz Republike Slovenije i Republike Hrvatske te se ujedno daje i njihova analiza.
\end{abstract}

Ključne riječi: zdravstvena ustanova; pravo osobnosti; imovinska šteta; neimovinska šteta; pacijent; liječnik; zdravstvena usluga.

Medicus curat, natura sanat. ${ }^{l}$

\section{UVOD}

U Republici Sloveniji (dalje: RS) i Republici Hrvatskoj (dalje: RH) glavni nositelji zdravstvene djelatnosti su zdravstvene ustanove. Prema pravnoj regulaciji tih zemalja zdravstvenu ustanovu može osnovati svaka pravna i fizička osoba, naravno,

* Dr. sc. Jakob Nakić, docent, umirovljeni zamjenik Županijskog državnog odvjetništva u Rijeci, jakobnakic@yahoo.com.

** Dr. sc. Loris Belanić, izvanredni profesor, Sveučilište u Rijeci, Pravni fakultet; lorisb@pravri. hr.

Ovaj rad je financiralo Sveučilište u Rijeci projektom Pravni aspekti restruktuiranja trgovačkih društava i tranzicija prema novoj kulturi korporativnog upravljanja (uniri-drustv-18-43).

1 Liječnik liječi, priroda ozdravljuje. Potječe iz djela Regimen Sanitatis Salernitanum, edtion 1607., dostupno na: http://worldofquotes.com/topic/Medicine/index.html, stranica posjećena 12. prosinca 2018. 
uz uvjete utvrđene zakonom..$^{2,3}$

Imajući na umu tko je osnivač ustanova one mogu biti javne i privatne. ${ }^{4}$ Zdravstvene ustanove obavljaju specifičnu djelatnost zaštite zdravlja građana i njezinim obavljanjem dolazi do neposrednog odnosa zdravstvene ustanove i pacijenta. Stoga se može prihvatiti mišljenje Radišića ${ }^{5}$ da su obveze zdravstvene ustanove liječnika spram pacijenta trojake i to: profesionalne (stručne), moralne i pravne s tim da granice među njima nisu čvrste i jasne.

Kao i u svakoj djelatnosti tako i u zdravstvenoj djelatnosti mogu nastati štete njezinim korisnicima. Posljednjih godina svjedočimo naglom porastu tužbi, i u RS u RH, zbog šteta nastalih u pružanju zdravstvene usluge s vrlo visoko postavljenim tužbenim zahtjevima i dugim parničnim postupcima.

Pravni sustavi obje zemlje pravo na naknadu štete, pa i one nastale u zdravstvu, (po)vezuju s pravima osobnosti. ${ }^{6,7}$

Koliko je tužbi hrvatskih građana do sada podneseno protiv zdravstvenih ustanova? Koliko su teške parnice koje se vode? Koliko je slučajeva riješeno u korist tužitelja te koliko su milijuna kuna na temelju naknada za štetu zbog nesavjesnog liječenja i liječničke pogreške, do sada isplatile hrvatske bolnice i domovi zdravlja? ${ }^{8}$

2 Vidi čl. 3. Zakona o zdravstveni dejavnosti, Uradni list (dalje: Ur. 1.), št. 23/05 - uradno prečiščeno besedilo, 15/08 - ZPacP, 23/08, 58/08 - ZZdrS-E, 77/08 - ZDZdr, 40/12 - ZUJF, 14/13, 88/16 -ZdZPZD, 64/17, dalje: ZZD/Slo) prema kojem: »Izvajalci zdravstvene dejavnosti so domače in tuje pravne in fizične osebe, ki so pridobile dovoljenje ministrstva, pristojnega za zdravje, za opravljanje zdravstvene dejavnosti.«

3 Prema odredbi čl. 35. Zakona o zdravstvenoj zaštiti (Narodne novine - dalje: NN, br. 150/08, 71/10, 139/10, 22/11, 84/11, 154/11, 12/12, 35/12, 70/12, 144/12, 82/13, 159/13, 22/14, 154/14, 70/16, 131/17, dalje: ZZZ/Hr):

Zdravstvenu djelatnost obavljaju zdravstvene ustanove, trgovačka društva i privatni zdravstveni radnici pod uvjetima i na način propisan ovim Zakonom, Zakonom o obveznom zdravstvenom osiguranju, Zakonom o ustanovama, Zakonom o trgovačkim društvima i Zakonom o koncesijama. Od 1. siječnja 2019. na snazi je novi Zakon o zdravstvenoj zaštiti, NN, br. 100/18. Vidi čl. 70.

4 Pobliže vidi kod Bauer, T., Lekarniška dejavnost - javna služba ali gospodarska dejavnost, magistarska radnja, Maribor, Univerzitet u Mariboru, Pravni fakultet, 2016., str. 7, 46-77. Javna ustanova je ustanova koja se osniva za obavljanje određenih djelatnosti (odgoj, obrazovanje, zdravstva, znanost, bibliotečna djelatnost i dr.) ili dijela tih djelatnosti ako je zakonom određeno da se obavljaju kao javna služba. Petrović, S., Pravni oblici pravnih osoba za obavljanje djelatnosti - pretpostavke i posljedice, Zbornik Pravnog fakulteta u Zagrebu, vol. 56, Posebni broj 2006., str. 87-127. Dostupno i na: https://hrcak.srce.hr/6429, mrežna stranica posjećena 12. prosinca 2018.

5 Radišić, J., Medicinsko pravo, Beograd, Nomos, 2004., str. 53. i 54.

6 Za RH pobliže vidi čl. 19. i 1045. Zakona o obveznim odnosima, NN, br. 35/05, 41/08, 125/11, 78/15, 29/18, dalje: ZOO/Hrv. Vidi čl. 21. i 23. st. 1. Ustava Republike Hrvatske, NN, br. 56/90, 135/97, 08/98, 113/00, 124/00, 28/01, 41/01, 55/01, 76/10, 85/10, 05/14, dalje: Ustav RH.

7 Za RS vidi odredbe čl. 134. i 179. Obligacijskog zakonika, Ur. 1, št. 97/07 - uradno prečiščeno besedilo, 64/16 - odl. US, 20/18 - OROZ631, dalje: OZ/Slo. Vidi i čl. 35. Ustava Republike Slovenije, Ur. 1. št. 33/91-I, 42/97 - UZS68, 66/00 - UZ80, 24/03 - UZ3a, 47, 68, 69/04 - UZ14, 69/04 - UZ43, 69/04 - UZ50, 68/06 - UZ121,140,143, 47/13 - UZ148, 47/13 - UZ90,97,99 in 75/16 - UZ70a, dalje: Ustav RS.

8 Ova ista pitanja postavili su i novinari, pobliže vidi na: https://www.tportal.hr/vijesti/clanak/ 
U RH do cjelovitog i potpunog odgovora nije bilo moguće doći, međutim u RS se može naći odgovor barem za određeno razdoblje. ${ }^{9,10}$

\section{IMOVINSKA I NEIMOVINSKA ŠTETA - OPĆI PRIKAZ}

\subsection{Republika Slovenija}

Slovenska pravna teorija definira prava osobnosti kao prava čovjeka koja se odnose na njegovu osobu i njegove osobnosti, kao primjerice pravo na život, pravo na osobno dostojanstvo, pravo na tjelesnu i duševnu cjelovitost, prava na sigurnost, pravo slobode izražavanja i sl. ${ }^{11}$

Odgovornost za štetu uređuje OZ/Slo koji u članku 132. daje definicije imovinske i neimovinske štete. Imovinska šteta, u najširem smislu, svaka je radnja zadiranja u imovinskopravnu sferu drugoga, koja je zaštićena imovinskopravnim pravima kojih je on nositelj. Pravno, nije svaka imovinska šteta pravno priznata šteta. Navedena odredba propisuje da je pravno priznata imovinska šteta samo ono kršenje prava drugoga koja može prouzročiti bilo smanjenje imovine oštećenog bilo sprečavanje povećanja imovine. ${ }^{12}$ Članak 132. OZ/Slo opće je pravilo o pravno priznatim štetama, a članak 168. istog zakona ima narav posebnog pravila. ${ }^{13}$ Način na koji će se uspostaviti prijašnje stanje, ono prije štete, ovisi o pojavnom obliku štete.

Neimovinska šteta, ${ }^{14}$ svaka je promjena u pravno zaštićenoj sferi oštećenog koje za posljedicu nema umanjenje njegove imovine. Takvim štetama smatraju se tjelesne i

podaci-o-tuzbama-protiv-bolnica-kriju-se-od-javnosti-20120320, mrežna stranica posjećena 12. prosinca 2018.

9 Primjerice vidi »Projekt Šilih« Poročilo o analizi kaznenskih in pravdnih spisov ter o raziskavi Ministarstva za zdravje o stanju na področju zagotavljanja učinkovitega (sodnega) varstva $\mathrm{v}$ primeru kršitve pravice pacienta do primerene, kakovostne in varne zdravstvene obravnave, dostupno na: www.mz.gov.si/...si/.../zdravstveno_varstvo/Porocilo_Silih_1.doc, mrežna stranica posjećena 12. prosinca 2018. Tako nalazimo podatak da je 2012. do 2017 . bilo ukupno 289 tužbi protiv zdravstvenih ustanova za naknadu štete, i to: 2012. - 44 predmeta, 2013 - 51 predmet, 2014. - 38 predmeta, 2015 - 75 predmeta, 2016. - 58 predmeta i 2017. -23 predmeta. Od ukupnog broja predmeta čak njih $176(61 \%)$ odnosi se na zdravstvenu pogrešku! U 10 predmeta su tužitelji bili i posredni oštećeni (roditelji, braća i sestre). Vidi i tamo prikazanu sudsku praksu.

10 Premda je i u RH poveliki broj sudskih tužbi spram zdravstvenih ustanova nakon predmeta Bajić protiv RH (Zahtjev br. 41108/10, dostupno na: https://uredzastupnika.gov.hr/UserDocsImages// arhiva//BAJI\%C4\%86, \%20presuda.pdf, mrežna stranica posjećena 12. prosinca 2018., nadležna tijela do sada još nisu provela analizu kaznenih i građanskih predmeta u kojima se razmatra šteta nastala u zdravstvenim ustanovama. Prema neformalnim saznanjima samo jedna bolnica imala je tijekom 2017. postupaka za naknadu štete u visini od 20.000.000,00 kn.

11 Vidi Juhart, M. et al., Uvod v civilno pravo, Ljubljana, Uradni list, 2016., str. 263.

12 Pobliže vidi u Plavšak, N., Juhart, M., Vrenčur, R., Obligacijsko pravo, splošni del, Ljubljana, GV Založba, 2009., str. 524 i 758.

13 Ibid., str. 611-614.

14 Za koju se često rabe i izričaji nematerijalna, moralna, idealna šteta. Pobliže vidi u Valenti, V., Nepremoženjska škoda: ureditev v italijanskem pravnem redu, magistarsko delo, Univerzitet u Ljubljani, Ljubljana, Pravni fakultet, 2018., str. 27-30. 
duševne boli, strah i umanjenje ugleda pravne osobe. ${ }^{15}$ Najvažniji institut građanskog prava u pogledu zaštite prava osobnosti je novčana naknada za neimovinsku štetu. ${ }^{16}$ Prema OZ/Slo nije svaki napad na pravo osobnosti ujedno i temelj za pravno priznatu neimovinsku štetu. Oštećeni će imati pravo na naknadu štete samo ako je imao za posljedicu tjelesne, duševne bolove ili strah. Slovenska sudska praksa zastupa stajalište da moraju biti dokazani svi elementi građanskog delikta tj. odštetne odgovornosti, dakle protupravno djelovanje, šteta, uzročna veza i odgovornost za štetu. ${ }^{17}$

\subsection{Republika Hrvatska}

ZOO/Hrv u članku 1046. štetu određuje kao umanjenje nečije imovine (obična šteta), sprječavanje povećanja imovine (izmakla korist) i povredu prava osobnosti ${ }^{18}$ (neimovinska šteta).

Dakle, imovinskim štetama smatraju se obična šteta i izmakla korist.

ZOO/Hrv je u naš pravni poredak uveo, tzv. objektivni koncept neimovinske štete, te prema članku 1046. ZOO/Hrv neimovinska šteta povreda prava osobnosti, ${ }^{19}$ a ne, kao što je bilo do tada, fizičke i psihičke boli te strah kao svojevrsne psihološke emanacije povrede prava osobnosti. Po tom novom konceptu, već je sama povreda prava osobnosti neimovinsku štetu. Navedenom odredbom neimovinska šteta se definira kao povreda prava osobnosti. Što se smatra pravom osobnosti određuje odredba članka 19. ZOO/Hrv te u stavku 1. propisuje da svaka fizička i pravna osoba ima pravo na zaštitu svojih prava osobnosti pod pretpostavkama određenim zakonom. Stavak 2. određuje da se pod pravom osobnosti smatra pravo na život, tjelesno i duševno zdravlje, ugled, čast, dostojanstvo, ime, privatnost osobnog i obiteljskog

15 Članak 132. OZ/Slo ovako ih definira: Škoda je zmanjšanje premoženja (navadna škoda), preprečitev povečanja premoženja (izgubljeni dobiček), pa tudi povzročitev telesnih ali duševnih bolečin ali strahu drugemu ter okrnitev ugleda pravne osebe (nepremoženjska škoda). [Šteta je umanjenje imovine (stvarna šteta), sprječavanje povećanja imovine (izmakla dobit), kao i prouzročenje drugome tjelesnih i duševnih boli ili straha te povreda ugleda prave osobe (neimovinska šteta),- prijevod autora].

16 Toplak, L., Civilno pravo, Splošni del civilnega prava, Maribor, Pravni fakultet u Mariboru, 2002., str. 252-254.

17 Vidi Lampe, R., Varovanje osebnostnih pravic proti medijem, u Medijsko pravo, Ljubljana, Planet GV, 2009., str. 88.

18 O tome koje kontroverze može proizvesti naziv »pravo osobnosti« vidi kod Vodinelić, V. V., Prava ličnosti - stare i nove dileme o nazivu i još ponečem, Liber amicorum Aldo Radolović, Zbornik radova, uredili: Z. Slakoper, M. Bukovac Puvača, G. Mihelčić, Sveučilište u Rijeci, Pravni fakultet, Rijeka, 2018., str. 259-300.

19 Ovdje valja ukazati kako je prvi doktorat na temu prava osobnosti na prostoru današnje RH napisao Aldo Radolović pod nazivom Pravo ličnosti kao kategorija građanskog prava, Pravni fakultet u Zagrebu, 1985. Od novijih radova vidi u bilješci 20. Pionir u toj temi u RS je Finžgar, A., Osebnostne pravice, Ljubljana, Slovenska akademija znanosti i umetnosti, 1985., vidi i prijevod na srpski Prava ličnosti, Beograd, Službeni list SFRJ, 1988. 
života, slobodu i dr. ${ }^{20,21}$

Svaka povreda prava osobnosti, iako je time objektivno nastala neimovinska šteta (čl. 1046. ZOO/Hrv), ne znači i bezuvjetno pravo oštećenika na isplatu pravične novčane naknade. Sud će dosuditi pravičnu novčanu naknadu u slučaju povrede prava osobnosti samo ako nađe da težina povrede i okolnosti slučaja opravdavaju takvu naknadu (čl. 1100 st. 1 ZOO/Hrv).

Stoga su, sudovi dužni najprije utvrditi je li neka štetna radnja povreda prava osobnosti iz čl. 19. ZOO/Hrv, a potom odlučiti je li navedena povreda takvog značenja (težina povrede i okolnosti slučaja) da opravdava dosuđenje pravične novčane naknade. Ovdje ukazujemo da fizičke boli, duševne boli i strah po ZOO/Hrv više nisu samostalni oblik povrede prava osobnosti. ${ }^{22}$ No, bolovi i strah nisu potpuno izostavljeni iz odlučivanju o visini pravične novčane naknade. Izrijekom je propisano da će sud, pri odlučivanja o visini pravične novčane naknade, voditi računa o jačini i trajanju povredom izazvanih fizičkih i duševnih boli te straha (čl. 1100 st. 2 ZOO/ Hrv). Oni su jedno od mjerila ${ }^{23}$ težine povrede prava osobnosti odnosno, visine pretrpjele neimovinske štete i s tim u vezi mogući kriterij odabira oblika popravljanja neimovinske štete. ${ }^{24}$

$\mathrm{Na}$ štete koje nastanu pri pružanju zdravstvenih usluga u hrvatskom pravu mogu se primijeniti kako pravila ugovorne odgovornosti i pravila izvanugovorne (deliktne) odgovornosti. ${ }^{25}$ Oštećenik je taj kojemu je prepušten izbor po kojim će pravilima zahtijevati naknadu štete. Razlika između tih dviju vrsti odgovornosti tiče se pretpostavki koje moraju biti ispunjene. Kod deliktne odgovornosti to su sljedeće pretpostavke, a koje imaju ujedno važnost općih pretpostavki odgovornosti za

20 Pobliže vidi Klarić, P., Vedriš, M., Građansko pravo, 9., izmijenjeno i dopunjeno izdanje, Zagreb, Narodne novine, 2006., str. 104; Gavella, N., Osobna prava, I. dio, Zagreb, Pravni fakultet Sveučilišta u Zagrebu, 2000., str. 13; Radolović, A., Pravo osobnosti u novom Zakonu o obveznim odnosima, Zbornik Pravnog fakulteta Sveučilišta u Rijeci, vol. 27., 1/2006., str. 129-170, dostupno i na: https://hrcak.srce.hr/8204, mrežna stranica posjećena 12. prosinca 2018; id., Specifični postupovnopravni problemi u zaštiti prava osobnosti, Zbornik Pravnog fakulteta u Zagrebu, vol. 63, 3-4/2013., str. 695-715, dostupno na https://hrcak.srce.hr/109726; Baretić, M., Pojam i funkcije neimovinske štete prema novom Zakonu o obveznim odnosima, Zbornik Pravnog fakulteta u Zagrebu, vol. 56, Posebni broj 2006., str. 461-500, dostupno i na: https://hrcak.srce.hr/6441, mrežne stranica posjećena 12. prosinca 2018.

21 ZOO iz 1991., NN, br. 53/91, 73/91, 111/93, 3/94, 7/96, 91/96, 112/99, 88/01, dalje: ZOO/91, taksativno je određivao oblike duševnih boli zbog kojih se mogla dosuditi pravična novčana naknada, a novi ZOO, iz 2005., ih određuje samo primjerično. Stoga je lista mogućih povreda prava osobnosti neograničena.

22 Pobliže na što sve mora sudu paziti kod suđenja o povredi prava osobnosti vidi kod Crnić, I., Pravo fizičke osobe na popravljanje neimovinske štete u: Barbić, J. et al., Naknada štete u primjeni novog Zakona o obveznim odnosima, Zagreb, Narodne novine, 2005., str. 19-40, Crnić, I., Parnični postupak i naknada štete, Zagreb, Organizator, 2008., str. 93-94, 166-167.

23 Ostala mjerila koja sudovi uzimaju u obzir pri odlučivanju o visini pravične novčane naknade jesu: cilj kojemu služi takva naknada i da se pravičnom novčanom naknadom ne pogoduje težnjama koja nisu spojive s njezinom naravi i društvenom svrhom (čl. 1100. st. 2. ZOO/Hrv).

24 Klarić P., Vedrišs, M., op. cit., str. 591.

25 Klarić, P., op. cit., str. 390. 
štetu: ${ }^{26}$ 1) subjekti odgovornosti za štetu, 2) štetna radnja 3), šteta, 4) uzročnost i 5) protupravnost. Kod ugovorne odgovornosti pretpostavke su sljedeće:27 1) postojanje ugovora (primjerice ugovora o zdravstvenoj usluzi između bolnice i pacijenta), 2) povreda ugovorne obveze, $\mathrm{tj}$. neispunjenje obveze dužnika (ako zdravstvena ustanova nije uopće ispunila svoju obvezu, ili nije ispunila onako kako je ugovoreno, ili je zakasnila s ispunjenjem), 3) šteta nanesena vjerovniku (tj. pacijentu), 4) postojanje uzročne veze između štetne radnje, tj. povrede ugovorne obveze i prouzročene štete, 5) postojanje protupravnosti odnosno izostanak zakonom predviđenih okolnosti za oslobođenje dužnika od odgovornosti. Odredbe o izvanugovornoj odgovornosti za štetu su opće odredbe o odgovornosti za štetu, a ZOO/Hrv je određeno da će se one primjenjivati i na ugovornu odgovornost ukoliko nije drukčije propisano. ${ }^{28}$

Spomenimo $\mathrm{i}$ to da se u hrvatskom pravu za odgovornost kod šteta nastalih pružanjem zdravstvene usluge primjenjuju pravila o subjektivnoj odgovornosti kod koje se krivnja pretpostavlja. ${ }^{29}$ Dakle, pored općih pretpostavki odgovornosti traži se i postojanje krivnje zdravstvene ustanove/liječnika. Pritom se njihova pretpostavlja, a liječnik odnosno zdravstvena ustanova da bi se oslobodili odgovornosti moraju dokazati da su radili prema pravilima i standardima struke i da nema njihove krivnje. Oštećeniku, tj. pacijentu preostaje dokazivanje uzročne veze između štetne radnje i prouzročene štete. $S$ tim u vezi postavlja se pitanje što se smatra štetnom radnjom kod šteta nastalih pružanjem zdravstvene usluge. Klarić navodi četiri grupe takvih štetnih radnji: ${ }^{30} 1$ ) povreda pravila zdravstvene struke (liječnička pogreška), 2) povreda prava na tjelesni integritet (liječenje bez pristanka pacijenta), 3) povreda obveze pružanje hitne medicinske pomoći i 4) povreda obveze sklapanja ugovora o zdravstvenoj usluzi.

Potrebno je i navesti da za pogreške koje zdravstveni radnik počini u radu ili u svezi s radom odgovara zdravstvena ustanova (primjerice bolnica) kao poslodavac (čl. 1061. st. 1. ZOO/Hrv). Zdravstvena ustanova ima pravo regresa prema zdravstvenom radniku koji je štetu skrivio namjerno ili krajnjom nepažnjom i to u roku od šest mjeseci od dana isplaćene naknade štete (čl. 1061. st. 3. ZOO/Hrv). Ako je zdravstveni radnik štetu uzrokovao namjerno, oštećeni ima pravo zahtijevati naknadu štete i neposredno od zdravstvenog radnika (primjerice liječnika - čl. 1061. st. 2. ZOO/Hrv).

\section{OSNIVAČI ZDRAVSTVENIH USTANOVA I NJIHOVA ODGOVORNOST ZA ŠTETU}

Osim toga tko je osnivač zdravstvenih ustanova, često se u teoriji postavlja i pitanje je je li zdravstvena djelatnost javna ili gospodarska djelatnost. U RS zdravstvena djelatnost koju obavljaju javni zavodi i koncesionari u zdravstvu obavlja se u jednom

26 Klarić, P., Vedriš, M., op. cit., str. 583-584.

27 Crnić, I., Naknada štete, Zagreb, Organizator, 1995., str. 165-169; Gorenc, V., et al., Komentar Zakona o obveznim odnosima, Zagreb, RRIF, 2005., str. 503-506.

28 Vidi čl. 349. ZOO/Hrv.

29 Klarić, P., op. cit., str. 392. do 393. VSRH, Rev-3118/1993, od 1. ožujka 1995. Izbor odluka, 1/1997, odl. br. 19.

30 Klarić, P., op. cit., str. 398. 
dijelu kao javna služba, a u drugom kao gospodarska djelatnost. ${ }^{31}$

U RH zdravstvena djelatnost obavlja se kao javna služba, ${ }^{32}$ pa je za zaključiti da je u RH prihvaćen javnopravni model pružanja zdravstvene usluge. ${ }^{33}$

\subsection{Republika Slovenija}

I u RS postoji propis lex generalis o ustanovama, a to je Zakon o ustanovah ${ }^{34}$ koji ne sadrži odredbe o solidarnoj i neograničenoj odgovornosti osnivača za obveze ustanove. Međutim, postoji i Zakon o zavodih ${ }^{35}$ koji u članku 1. nabraja za koje se djelatnosti osnivaju zavodi, i jedna od njih je zdravstvena djelatnost, dok u članku 49. ZZ/Slo određuje da osnivač zavoda solidarno odgovara za obveze zavoda.

U RS sukladno ZZD/Slo osnivač javnih zavoda koji obavljaju zdravstvenu djelatnost ${ }^{36}$ je država i odgovara solidarno ${ }^{37}$ i neograničeno za obveze zdravstvenih ustanova čiji je osnivač.

Sukladno članku 5. ZZD/Slo osnivači zdravstvenih ustanova u RS su općine za primarnu službu, i to osnovnu zdravstvenu zaštitu i ljekarništvo, RS za primarnu službu na demografski ugroženim područjima, službe za zdravstvenu zaštitu studenata, zdravstvene službe sekundarne i tercijarne naravi, i to specijalističke ambulante i bolnice, klinike, klinički instituti i sl.

Zdravstveni zavod sredstva za rad stječe iz sredstava ustanovljenih aktima zavoda, iz cijene izvršene usluge, iz ugovora s zavodom za zdravstveno osiguranje i iz drugih izvora dopuštenih zakonom.

31 Pobliže vidi kod Bauer, T., Lekarniška dejavnost - javna služba ali gospodarska dejavnost, magistarska naloga, Univerza v Mariboru, Maribor, Pravna fakulteta, 2016., str. 7-14 i 87; Bohinc, R., Tržna dejavnost in preoblikovanje javnih zavodov, Lex localis, Revija za naročila in javne finance, letnik V, 3/2007., str. 1-13; Bohinc, R., Tičar, B., Pravo zavodov, Koper, Univerza na Primorskem, Fakulteta za managment, 2012., str. 48-78.

32 Vidi čl. 24. ZZZ/Hrv.

33 Pobliže vidi kod Nikšić, S., Ugovor o zdravstvenoj usluzi, doktorska disertacija, Zagreb, Pravni fakultet Sveučilišta u Zagrebu, 2007., str. 78-96. I u pravu Republike Srbije zastupa se takav stav. Vidi Mujović Zornić., H., Pacijentova prava - univerzalnost i evropski koncept, Zbornik radova Aktualnosti građanskog i trgovačkog prava i pravne prakse, 3/2005, str. 255.

34 Ur. 1., št. 60/95, 53/05, 70/05, 91/05, dalje: ZU/Slo.

35 Ur. 1., št. 12/91, 8/96, 36/00 - ZPDZC in 127/06 - ZJZP, dalje: ZZ/Slo, u čl. 1. daje definiciju zavoda kao (...) organizacije, ki se ustanovijo za opravljanje dejavnosti vzgoje in izobraževanja, znanosti, kulture, športa, zdravstva, socialnega varstva, otroškega varstva, invalidskega varstva, socialnega zavarovanja ali drugih dejavnosti, če cilj opravljanja dejavnosti ni pridobivanje dobička. U čl. 49. ZZ/Slo propisuje da osnivač zavoda odgovara za obveze zavoda.

36 Tako, primjerice u čl. 2. Statuta Univerzitetnega kliničnega centra Ljubljana (dostupan na: https://www.kclj.si/dokumenti/statut.pdf, stranica posjećena dana 12. prosinca 2018.) stoji: » Ustanovitelj UKC je Republika Slovenija. Ustanoviteljske pravice in obveznosti izvršuje Vlada Republike Slovenije."

37 O solidarnoj odgovornosti pobliže vidi u Perović, S. M., Solidarna odgovornost u obligacionim odnosima, doktorska disertacija, Beograd, Univerzitet u Beogradu, Pravni fakultet, 2018., str. 106-138; Nakić, J., Republika Hrvatska kao solidarni dužnik, Liber amicorum Aldo Radolović, Zbornik radova, Sveučilište u Rijeci, Pravni fakultet, Rijeka, 2018., str. 551-576; Karamarković, L., Solidarna odgovornost dužnika i njihov procesni značaj, Beograd, Pravni fakultet Univerziteta Union u Beogradu, 2008., str. 23-43 i 118-125. 
Prema članku 61. ZZD/Slo svaki liječnik, koji radi neposredno s bolesnicima, mora biti osiguran od odgovornosti za štetu ${ }^{38}$ koja može nastati u njegovom radu. Zdravstvena ustanova osigurava liječnika zaposlenog u toj ustanovi. ${ }^{39}$

U posljednjih pet godina nismo uspjeli naći podatak da je u RS bila tužena kao solidarni dužnik s zdravstvenim ustanovama čiji je ona osnivač.

\subsection{Republika Hrvatska}

Prema članku 44. ZZZ/Hrv osnivači zdravstvenih ustanova u RH su:

1) država - a) za državni zdravstveni zavod, kliniku kao samostalnu ustanovu, kliničku bolnicu i klinički bolnički centar; b) za potrebe pružanja zdravstvene zaštite djelatnicima Ministarstva obrane i pripadnicima Oružanih snaga RH, u sastavu Ministarstva obrane i Oružanih snaga RH, osniva se vojno zdravstveno središte Ministarstva obrane i Oružanih snaga RH kao vojna zdravstvena ustanova; c) za zdravstvenu ustanovu radi pružanja zdravstvene zaštite osobama lišenih slobode;

2) jedinice područne (regionalne) samouprave - za opću bolnicu i dom zdravlja, zavod za hitnu medicinu i zavod za javno zdravstvo, polikliniku, lječilište, ustanovu za zdravstvenu njegu, ustanovu za palijativnu skrb i ljekarničku ustanovu;

3) fizičke ili pravne_osobe - za polikliniku, lječilište, ustanovu za zdravstvenu njegu, ustanovu za palijativnu skrb i ljekarničku ustanovu;

4) fizičke osobe sa završenim sveučilišnim diplomskim studijem zdravstvenog usmjerenja za ustanovu za zdravstvenu skrb.

Sukladno odredbe članka 8 . stavak 2. ZZD/Hrv RH osigurava sredstva za investicijsko ulaganje i investicijsko i tekuće održavanje zdravstvenih ustanova čiji je osnivač kao i pokriće gubitka zdravstvenih ustanova čiji je osnivač. I članak 56. ZZD/ Hrv propisuje ako u obavljanju djelatnosti zdravstvene ustanove nastane gubitak, ${ }^{40}$

38 O poredbenom prikazu sustava osiguranja u zdravstvu vidi kod Vamberger, E., Zavarovanje odgovornosti zdravnikov v Sloveniji, Nemčiji in Angliji, magistarski rad, Maribor, Doba fakultet za uporabne poslovne in družbene študije, 2012., str. 22-70.

39 Visinu osigurane svote za svaku specijalizaciju posebno određuje za svaku godinu Zdravniška zbornica Slovenije uz suglasnost nadležnog ministarstva. Zadnja odluka o visini osiguranja donijeta je 2018. i to s Sklepom o zavarovanju zdravnikov in zobozdravnikov za škodo, ki bi lahko nastala pri njihovem delu, dostupno na:https://webcache.googleusercontent. com/search?q=cache:aCEWTcS12EoJ:https://e-uprava.gov.si/.download/edemokracija/ datotekaVsebina/367536\%3Fdisposition\%3Dattachment $+\& \mathrm{~cd}=3 \& \mathrm{hl}=\mathrm{hr} \& \mathrm{ct}=\mathrm{clnk} \& \mathrm{gl}=\mathrm{hr}$, mrežna stranica posjećena 12. prosinca 2018., i utvrđena je u iznosu od najmanje $130.000,00$ eura, koja vrijedi za 2019. i za sve specijalnosti.

40 U primjeni ove odredbe može se postaviti pitanje obuhvaća li izričaj »gubitak« i izričaj »šteta«. Sudovi se u svojim pravorijecima uglavnom referiraju, u odnosu na zdravstvene ustanove, samo na čl. 59. ZU/Hrv, dok se na odredbe ZZZ/Hrv uopće ne osvrću. Primjerice Županijski sud u Rijeci u presudi Gž-881/16, od 30. ožujka 2017., dostupna na: http://sudovi.pravosudje.hr/zsri/, mrežna stranica posjećena 12. prosinca 2018., navodi: Stoga proizlazi pravilnim zaključak suda prvog stupnja o odgovornosti 2.-go tuženika kao Ustanove koja se bavi pružanjem liječničke skrbi temeljem odredbe čl. 1045. st. 1. i 2. ZOO-a, te 1.-vo tužitelja (očito pogrešno treba pisati tuženoga-op.a.) kao osnivača te Ustanove i to temeljem čl. 59. Zakona o ustanovama (,,Narodne novine" broj: 76/93, 29/97, 47/99 i 35/08), a zbog ne pružanja adekvatne liječničke skrbi 1.-vo tužitelju. "Općinski sud u Rijeci u prvostupanjskoj presudi, u istom predmetu (neobjavljena), 
pokriva ga osnivač prema odredbama Zakona o ustanovama. ${ }^{41} \mathrm{ZU} / \mathrm{Hrv}$ u članku 59. propisuje kako ustanove cijelom svojom imovinom odgovaraju za svoje obveze kao i da osnivač ustanove solidarno ${ }^{42}$ i neograničeno odgovara za obveze ustanove.

U RH članak 124. ZZD/Hrv određuje da je poslodavac obvezatan sve zdravstvene radnike koji neposredno u vidu zanimanja pružaju zdravstvenu zaštitu stanovništvu osigurati od štete koja bi mogla nastati u provođenju zdravstvene zaštite. ${ }^{43}$ Prema podatcima iz 2004. ${ }^{44}$ od ukupnog broja profesionalnih liječnika u RH osigurano jedva oko $10 \%$ !

U RH se češće nego u RS događa da uz zdravstvenu ustanovu bude tužen i njezin osnivač. ${ }^{45}$

\section{PRAVNI ODNOS DAVATELJA I PRIMATELJA ZDRAVSTVENE USLUGE}

Pravni odnos koji nastaje između pravnih i/ili fizičkih osoba koje pružaju zdravstvene usluge i pacijenta bitan je da bi se mogla (raz)riješiti odgovornost za štetu koja može nastati u realizaciji pružanja zdravstvene usluge. ${ }^{46}$ Zato valja posebnu pažnju posvetiti analizi ugovora o pružanju zdravstvenih usluga, ali sudska praksa različito pristupa tim ugovorima u RS i RH.

Sudovi u RS vrlo često se bave tim problemom ${ }^{47}$ dok je kod sudova u RH to sporadično. Novija sudska praksa u RS odnos zdravstvene ustanove i pacijenta kod izvođenja medicinskih zahvata sve više priznaje kao ugovorni odnos. ${ }^{48} \mathrm{U}$ literaturi

iskazao je da ,, 1. tuženik Republika Hrvatska kao osnivač Kliničkog bolničkog centra Rijeka primjenom odredbe čl. 59. Zakona o ustanovama solidarno odgovara sa 2. tuženikom za štetu nastalu 1. tužitelju. Drugostupanjska presuda potvrđena je presudom VSRH, Rev-x-848/17, od 31. listopada 2017., neobjavljeno.

41 NN, br. 76/93, 29/97, 47/99, 35/08, dalje: ZU/Hrv. Vidi čl. 59.

42 O solidarnoj odgovornosti države kao osnivača ustanova vidi kod Nakić, J., op. cit., str. 551576. U radu se obrađuje i problem regresnog potraživanja osnivača.

43 Pobliže vidi kod Proso, M., Sustavi osiguranja od odštetne odgovornosti u zdravstvenoj djelatnosti, Zbornik radova Pravnog fakulteta u Splitu, vol. 46, 2/2009., str. 359-372. Dostupno na: https://hrcak.srce.hr/38222, mrežna stranica posjećena 12. prosinca 2018.

44 Prema podacima iz članka Liječnici vs. pacijent, objavljenom u Jutarnjem listu, subota 28. kolovoza 2004. Novije podatke nismo uspjeli pronaći!

45 U RS ponajprije se tuži osiguravatelja pa onda zdravstvena ustanova. Nismo pronašli predmeta u kojima je tužena i RS. U RH najčešće se tuže zdravstvene ustanove, a tek potom i njihov osnivač. Nismo našli predmeta u kojima je tužen osiguravatelj.

$46 \mathrm{Za}$ razjašnjenje nastalih pitanja naknade štete početna točka je točno i precizno utvrditi postojanje i sadržaj odnosa između štetnika (zdravstvene ustanove) i oštećenog (pacijenta). Vidi i Ovčak Kos, M., Civilnopravna odgovornost zdravnika, Ljubljana, Aletheia, 2017., str. 2.

47 Primjerice presude Vrhovnog suda Republike Slovenije, dalje: VSS1, Cp-2868/14, od 3. prosinca 2014. ECLI:SI:VSLJ:2014:I.CP.2868.2014, I Cp-2523/2014, od 7. siječnja 2015., ECLI:SI:VSLJ:2015:I.CP.2523.2014., Cp-555/2016, od 16. ožujka 2017., ECLI:SI:VSCE:2017:CP.555.2016 i I CP-2257/2017, od 23. svibnja 2018., ECLI:SI:VSLJ:2018:I.CP.2257.2017.

48 Vidi odluku VSS1 II Ips-207/2015, od 14. siječnja 2016., ECLI:SI:VSRS:2016:II.IPS.207. u kojoj je izrečeno: »Razmerje med zdravnikom oz. zdravstveno ustanovo in bolnikom je 
se može naći mišljenje da se ugovor o zdravstvenim uslugama smatra ugovorom o djelu (podjemna pogodba). ${ }^{49}$ Takav je stav zauzimao i VSSl. ${ }^{50} \mathrm{U}$ novije vrijeme pravna teorija sve više zastupa mišljenje da se radi o ugovoru o nalogu (mandatu). ${ }^{51}$ Neki teoretičari zastupaju stav da se radi o neimenovanom tipu ugovora sui generis. ${ }^{52}$ Slovenski sudovi su i u razmatranim odlukama zauzimali stav da se radi o ugovoru o pružanju usluga. ${ }^{53}$

Sudovi u RH ne opterećuju se prečesto problemom pravnih odnosa koji nastaju između osoba koje pružaju zdravstvene usluge i pacijenta. Mali je broj presuda koje su dostupne stručnoj javnosti o toj temi, ali se iz njih može steći dojam da je Vrhovni sud Republike Hrvatske (dalje: VSRH) zauzeo stajalište da se radi o ugovoru o djelu. ${ }^{54}$ VSRH je opravdanje za takovu kvalifikaciju očito pronašao u pravnoj teoriji. ${ }^{55}$ Naravno, bilo je i drugačijim mišljenja. ${ }^{56}$ Klarić $^{57}$ smatra da se radi, o tzv.

praviloma pogodbene narave (izjema npr. velja, ko zdravnik ravna v nuji). Obveznost bolnika je plačilo opravljene storitve, ki ga opravi sam ali preko skladov zdravstvenega zavarovanja, obveznost zdravnika pa je izpolnitev dogovorjene zdravstvene storitve, ki ima običajno značilnosti obligacije prizadevanja. V pravni teoriji se zdravniška pogodba opredeljuje kot podjemna pogodba. Če zdravnik ne ravna v skladu s standardi, ki jih nalaga strokovna doktrina, in bolniku nastane škoda, gre za kršitev pogodbenega razmerja. Odločilno je vprašanje kršitve dolžne skrbnosti, to je ravnanje contra legem artis. V skladu z določili 239. in 240. člena Obligacijskega zakonika (v nadaljevanju OZ) se dolžnik svoje odgovornosti razbremeni z dokazom o ustrezni skrbnosti, dokazati pa mora tudi, da so obstajale okoliščine, zaradi katerih pogodbe ni mogel (pravilno) izpolniti, ki so bile nepremagljive oziroma neodvrnljive.«. Identično i II Ips 342/2014, od 22. siječnja 2015., ECLI:SI:VSRS:2015:II.IPS.342.2014.

49 Vidi kod Polajnar Pavčnik, A., Obligacijski vidik razmerja med bolnikom in zdravnikom, Pravo in medicina, Ljubljana, Cankarjeva založba, 2004., str. 731-733; Brus, M., Podjemna pogodba, Pravosodni bilten, št. 2/17, Ljubljana, Ministarstvo za pravosodje, 2017., str. 21.

50 Primjerice u odluci II Ips-342/2014, od 22. siječnja 2015., ECLI:SI:VSRS:2015:II.IPS.342.2014 i II Ips-207/2015, od 14. siječnja 2016., ECLI:SI:VSRS:2016:II.IPS.207.

51 Plavšak, N., Juhart, M., Obligacijski zakonik s komentarjem, 4. knjiga, Ljubljana, GV Založba, 2004., str. 199; Ovčak Kos, M., op. cit., str. 4, Mesojedec, T., Podjemna pogodba - pasti in zanke, dostupno na:, https://www.medicina-danes.si/268520?cctest\&, mrežna stranica posjećena 12. prosinca 2018.

52 Klarić, P., Odštetno pravo, Zagreb, Narodne novine, 2003., str. 385.

53 Vidi bilješku 80.

54 Vidi odluke VSRH, Rev-2156/91, od 8. siječnja 1992., ECLI:HR:VSRH:1992:1090, Rev1483/91, od 24. listopada 1991., ECLI:HR:VSRH:1991:4224.

55 Vidi kod Perović, S., Stojanović, D., Komentar Zakona o obligacionim odnosima, knjiga druga, Kragujevac, Kulturni Centar, Gornji Milanovac, Pravni fakultet Kragujevac, 1980., str. 290. Istovjetno i Blagojević, B. T., Krulj, V., Komentar Zakon o obligacionim odnosima, knjiga druga, Beograd, Savremena administracija, 1980., str. 78; Momčinović, H., Ugovori obveznog prava, prva knjiga, Zagreb, Narodne novine, 1987., str. 57. Indirektno možemo zaključiti da isto smatra i Gorenc, V., Zakon o obveznim odnosima, Zagreb, RRIF, 1998., str. 769-771.

56 Ovi autori spore da se radi o ugovoru o djelu, ali ne daju svoj stav koji bi ugovor to bio. Vidi Vedriš, M., Klarić, P., Građansko pravo, 8. izd., Zagreb, Narodne novine, 2004., str. 506; Vizner, B., Bukljaš, I., Komentar Zakona o obveznim (obligacijskim) odnosima, II. posebni dio, ugovori, 3. knjiga, Zagreb, Vlastita naklada, 1979., str. 541 i 656; Cigoj, S., Obligacijska razmerja, Zakon o obligacijskih razmerjah s komentarjem, Ljubljana, Uradni list SR Slovenije, 1978., str. 541 i 656.

57 Klarić, P., op. cit., str. 385. 
neimenovanom ugovoru sui generis. Ali isti autor ${ }^{58}$ ističe da se radi o ugovoru o djelu, ali bez obveze postizanja određenog rezultata u pružanju zdravstvene usluge. Bevanda $^{59}$ smatra da ugovor o djelu, obuhvaća i klasične ugovor o djelu ali i ugovore o uslugama. ${ }^{60}$

\subsection{Republika Slovenija - pravni izvori}

I za RS i RH valja ponajprije ukazati na neke međunarodne dokumente, koji ih obvezuju, kao UN-ova Opća deklaracija o pravima čovjeka, ${ }^{61}$ Konvencija o zaštiti ljudskih prava i temeljnih sloboda, ${ }^{62}$ Konvencija o zaštiti ljudskih prava i dostojanstva ljudskog bića u pogledu primjene biologije i medicine s dodatnim protokolima. ${ }^{63}$

Od propisa koji se mogu primijeniti na ugovore o pružanju zdravstvenih usluga valja ukazati na: Ustav RS, ${ }^{64} \mathrm{OZ} / \mathrm{Slo}, \mathrm{ZZD} / \mathrm{Slo}$, Zakon o zdravniški službi, ${ }^{65}$ Zakon o pacientovih pravicah, ${ }^{66}$ Zakon o opravljanju zdravstvenih poklicev v Republiki Sloveniji za državljane drugih članic Evropske unije ${ }^{67}$ te Zakon o zdravstvenem varstvu in zdravstvenem zavarovanju. ${ }^{68}$

Članak 51. Ustava RS pravo na zdravstvenu uslugu ubraja u čovjekova prava i temeljne slobode.

Za razliku od propisa u RH u RS nema definiranja zdravstvene djelatnosti kao djelatnosti od posebnog interesa za državu. U članku 3.a ZZD/Slo određuje da na temelju uloge domaće ili strane pravne ili fizičke osobe nadležno ministarstvo izdaje dozvole za obavljanje zdravstvene djelatnosti. Člankom 4. ZZD/Slo određeno je da se zdravstvena djelatnost kao javna služba obavlja u okviru mreže javne zdravstvene službe.

58 Klarić, P., Odgovornost zdravstvene ustanove i zdravstvenih djelatnika za štetu, prvi dio, Hrvatska pravna revija, br. 8/01, Zagreb, 2001., str. 17-35.

59 Bevanda, M., Ugovor između liječnika i pacijenta, Zbornik Pravnog fakulteta Sveučilišta u Rijeci, vol. 26, 1/2005, str. 307-338.

60 Ovaj stav vrlo argumentirano pobija Nikšić, S., op. cit., str. 221.

61 Dostupna na: https://www.ohchr.org/EN/UDHR/Documents/UDHR_Translations/src1.pdf, mrežna stranica posjećena 12. prosinca 2018.

62 NN, MU, br. 13/03, dalje: EKZLJPTS.

$63 \mathrm{NN}, \mathrm{MU}$, br. 13/03.

64 Čl. 51. Ustava RS propisuje:

Vsakdo ima pravico do zdravstvenega varstva pod pogoji, ki jih določa zakon.

Zakon določa pravice do zdravstvenega varstva iz javnih sredstev.

Nikogar ni mogoče prisiliti $k$ zdravljenju, razen v primerih, ki jih določa zakon.

65 Ur. 1. št. 72/06 - uradno prečiščeno besedilo, 15/08 - ZPacP, 58/08, 107/10 - ZPPKZ, 40/12 ZUJF, 88/16 - ZdZPZD, 40/17, 64/17 - ZZDej-K, 49/18, dalje: ZZS/Slo.

66 Ur. 1. št. 15/08, 55/17, dalje: ZZP/Slo.

67 Ur. 1. št. 86/02, 2/04, 88/16-ZdZPZD.

68 Ur. 1. št. 72/06 - uradno prečiščeno besedilo, 114/06 - ZUTPG, 91/07, 76/08, 62/10 - ZUPJS, 87/11, 40/12 - ZUJF, 21/13 - ZUTD-A, 91/13, 99/13 - ZUPJS-C, 99/13 - ZSVarPre-C, 111/13 - ZMEPIZ-1, 95/14 - ZUJF-C, 47/15 - ZZSDT, 61/17 - ZUPŠ in 64/17 - ZZDej-K. 


\subsection{Republika Hrvatska - pravni izvori}

Ustav RH u članku 21. i 23. stavak 1. pravo na samoodređenje u odnosu na liječnike i znanstvene eksperimente ubraja u krug osobnih i političkih prava i sloboda. Članak 58. i 69. pravo na zdravstvenu zaštitu i zaštitu zdravlja ubrajaju u ustavnu kategoriju gospodarskih, socijalnih i kulturnih prava. Od zakonskih izvora o zdravstvenoj djelatnosti u širem smislu možemo navesti ZOO/Hrv, Obiteljski zakon, ${ }^{69}$ Zakon o zaštiti potrošača ${ }^{70} \mathrm{i}$ dr. Od izvora u užem smislu valja navesti ZZZ/Hrv, Zakon o zaštiti prava pacijenata, ${ }^{71}$ Zakon o liječništvu, ${ }^{72}$ Zakon o obaveznom zdravstvenom osiguranju i zdravstvenoj zaštiti stranaca u Republici Hrvatskoj, ${ }^{73}$ Zakon o obveznom zdravstvenom osiguranju, ${ }^{74}$ Zakon o dobrovoljnom zdravstvenom osiguranju ${ }^{75}$ itd. ${ }^{76}$

Sukladno odredbi članka 24. ZZZ/Hrv zdravstvena djelatnost je djelatnost od interesa za RH koja se obavlja kao javna služba i koju po stručno medicinskoj doktrini i uz uporabu medicinske tehnologije obavljaju zdravstveni djelatnici pri pružanju zdravstvene zaštite, uz uvjete i na način propisan ZZZ/Hrv. Iz toga možemo zaključiti da se zdravstvena djelatnost obavlja kao javna službe neovisno o tome obavljaju li se zdravstvena ustanova, trgovačko društvo ili privatni zdravstveni djelatnik. $\mathrm{VSRH}^{77}$ je u svojoj praksi proširio pojam javne službe i na djelatnosti koje u svojoj

69 NN, br. $103 / 15$.

$70 \mathrm{NN}$, br. $41 / 14,110 / 15$.

71 NN, br. 169/04, 37/08, dalje: ZZPP/Hrv.

72 NN, br. 121/03, 117/08, dalje: ZL/Hrv.

$73 \mathrm{NN}, 80 / 13,15 / 18$.

$74 \mathrm{NN}$, br. $80 / 13,137 / 13$.

75 NN, br. 85/06, 150/08, 71/10.

76 Pobliže vidi kod Bošković, Z., Pogled u normativno i stvarno u zdravstvenom sustavu, JAHR, vol. 1, 2, Rijeka, Katedra za društvene i humanističke znanosti u medicini Medicinskog fakulteta Sveučilišta u Rijeci i Dokumentacijsko-istraživački centar za europsku bioetiku Fritz Jahr Sveučilišta u Rijeci, 2010., str. 250-265; Franjić, S., Ishodišni temelji medicinskog prava, JAHR, vol. 4, 8, Katedra za društvene i humanističke znanosti u medicini Medicinskog fakulteta Sveučilišta u Rijeci i Dokumentacijsko-istraživački centar za europsku bioetiku Fritz Jahr Sveučilišta u Rijeci, 2013., str. 857-870., Nikšić, op. cit., str. 30.

77 Vidi primjerice: Rev-735/98, od 21. studenog 2000., ECLI:HR:VSRH:2000:902, Rev1873/98, od 4. srpnja 2001., dostupno na: http://www.vsrh.hr, mrežna stranica posjećena 12. prosinca 2018., Rev-3017/98, od 8. svibnja 2002., ECLI:HR:VSRH:2002:4492, Rev11/99, od 5. rujna 2002., ECLI:HR:VSRH:2002:4465, Rev-170/99, od 11. ožujak 2003., ECLI:HR:VSRH:2003:1545, Rev-205/99, od 3. rujna 2002., ECLI:HR:VSRH:2002:4641, Rev-903/98, od 30. rujna 1998., ECLI:HR:VSRH:1998:355, Rev-575/99, od 23. srpanj 2002., ECLI:HR:VSRH:2002:4931, Rev-694/99, od 12. prosinca 2001., ECLI:HR:VSRH:2001:3543, Rev-2573/99, od 15. siječanja 2003., ECLI:HR:VSRH:2003:3826, Rev-3276/99, od 29. svibanja 2003., ECLI:HR:VSRH:2003:4076, Rev-1598/00, od 16. studenog 2000., CLI:HR:VSRH:2000:2872, Rev-2427/00, od 15. siječnja 2002., dostupno na: http://www. vsrh.hr, mrežna stranica posjećena 12. prosinca 2018., Rev-2860/00, od 22. listopada 2003., ECLI:HR:VSRH:2003:3128, Rev-684/01, od 16. srpnja 2003., ECLI:HR:VSRH:2003:1081, Rev-745/01, od 25. rujan 2003., ECLI:HR:VSRH:2003:4887, Rev-1331/01, od 10. rujna 2003., ECLI:HR:VSRH:2003:6569, Rev-221/02, od 11.lipanj2002.,ECLI:HR:VSRH:2002:3386, Rev521/02, od 28. svibnja 2002., ECLI:HR:VSRH:2002:5250, Rev-779/02, od 20. listopada 2004., ECLI:HR:VSRH:2004:2200, Rev-1200/02, od 11. veljače 2004., ECLI:HR:VSRH:2004:3004, Rev-306/03, od 9.ožujka 2005., ECLI:HR:VSRH:2005:2695, Rev-811/03, od 9. veljače 2005., 
biti predstavljaju javne usluge pa se to odnosi i na zdravstvene djelatnosti za koje zakonom nije izričito određeno da se obavljaju kao djelatnost javne službe.

U RH gotovo da i nema stručnog interesa za obradom problematike ugovora o pružanju zdravstvenih usluga. ${ }^{78}$ Sudska praksa se time bavi sporadično i nedovoljno metodično. $^{79}$

\section{PRIKAZ SUDSKOG PREDMETA IZ REPUBLIKE SLOVENIJE ${ }^{80}$}

Ženska osoba, tada stara 45 godina, zaprimljena je u bolnicu dana 4. srpnja 2002., zbog operacije postoperativne kile. Slijedećeg dana bila je zakazana operacija i u 12.25 sati je anesteziolog oštećenoj započeo s postupkom spinalne anestezije, a nakon toga je izveden kirurški zahvat. Na poslijepodnevnoj viziti oštećena se žalila na bolove u leđima te joj je prepisan lijek Ketonal. Dežurni liječnik je ponovno pozvan oko 19.00 sati zbog daljnjih bolova u leđima te je on tada pregledao i noge oštećene i ustanovio da su oba ekstremiteta flakcidna, ${ }^{81} \mathrm{o}$ čemu je obavijestio dežurnog anesteziologa koji je odredio terapiju lijekovima, ali je ujedno odredio i MRI ${ }^{82}$ kralježnice. Nakon toga je oštećena premještena na odjel neurokirurgije jer je MRI pokazao hematom pa je žurno učinjeno kirurško odstranjenje hematoma. Međutim, i unatoč uklanjanju hematoma oštećena je ostala paraplegičar.

Zbog štete pretrpljene u bolnici oštećena je zatražila naknadu štete u ukupnom iznosu od 37.899.465,00 SIT (što je oko 158.151,66 eura) i to za tjelesne boli, straha, bolova zbog unakaženosti te zbog smanjenja životnih aktivnosti, troškova lijekova i pomagala, prijevoznih troškova, gubitka na plaći te rentu. Tijekom postupka je mijenjala tužbeni zahtjev.

Oštećena je tužila solidarno osiguratelja i bolnicu.

Slovenski sud je, poradi ekonomičnosti postupka, ${ }^{83}$ međupresudom odlučio o osnovanosti tužbenoga zahtjeva utvrdivši da su tuženi solidarno odgovorni za štetni događaj od 5. srpnja 2002., s time da je osiguravatelj solidarno odgovoran do iznosa revaloriziranog limita osigurane svote.

Prvostupanjskom presudom ${ }^{84}$ oštećenoj je dosuđeno 225.000,00 eura s naslova neimovinske štete uz zakonske zatezne kamate. Zbog izgubljene zarade dosuđen joj je iznos od 64.040,44 eura uz zakonske kamate. Dosuđena joj je i renta u iznosu od 238,00 eura mjesečno. Na ime imovinske štete dosuđen joj je iznos od 1.102,76 eura

ECLI:HR:VSRH:2005:718, Rev-945/03, od 22. ožujka 2005., ECLI:HR:VSRH:2005:1761.

78 Ovdje moramo navesti gotovo pa jedino djelo koje se sveobuhvatno i sustavno bavi ugovorom o pružanju usluga u zdravstvu, a to je Nikšić. S., Ugovor o zdravstvenoj usluzi, doktorska disertacija, Pravni fakultet Sveučilišta u Zagrebu, 2007.

79 Tako VSRH u pravorijeku Rev-2156/91, od 8. siječnja 1992., ECLI:HR:VSRH:1992:1090.

80 Predmet Okružnog suda u Ljubljani, P-2135/03, P-1803/15 i P-747/17, neobjavljen, Viši sud u Ljubljani, I Cp-2868/14, ECLI:SI:VSLJ:2014:I.CP.2868.2014 i I Cp-3251/15, ECLI:SI:VSLJ:2016:I.CP.3251.2015 i VSS1, II Ips-94/15, ECLI:SI:VSRS:2015:II.IPS.94.2015.

81 Radi se o mlitavosti mišića.

82 Uređaj za magnetsku rezonanciju.

83 Presuda donijeta 13. studenog 2009., a tužba je podnijeta 2002.

84 Okružni sud u Ljubljani, P-2153/2003, od 5. listopada 2016. - neobjavljeno. 
uz zakonske zatezne kamate. ${ }^{85}$

Posredno oštećeni (suprug i djeca) u tužbenom zahtjevu tražili su naknadu neimovinske štete zbog teškog invaliditeta supruge i majke. OZ/Slo u članku 180. stavak 2 određuje da u slučaju naročito teškog invaliditeta neke osobe sud može dosuditi njezinom supružniku i djeci pravičnu novčanu naknadu za njihove duševne boli.

U odnosu na tužbene zahtjeve posredno oštećenih prvostupanjski sud dosudio je naknadu neimovinske štete i to suprugu u iznosu od 25.000,00 eura, s kamatama, a djeci svakom po 10.000,00 eura, s kamatama.

Drugostupanjski sud preinačio je prvostupanjsku odluku na način da je suprugu dosudio 30.000,00 eura, s kamatama, a djeci svakom po 12.000,00 eura, s kamatama.

Bitno je za istaknuti da u RS ne postoje, tzv. orijentacijski kriteriji, kao u RH, već se visina pravične novčane naknade za neimovinsku štetu regulira judikatima VSSl-a. ${ }^{86}$

Predmet Šilih ${ }^{87}$ koji je RS imala pred Europskim sudom za ljudska prava(dalje: ESLJP) bio je povod Vladi RS da izradi analizu tog predmeta, ali i svih predmeta naknade štete od zdravstvenih ustanova od 2012. do 2017.

\section{PRIKAZ SUDSKOG PREDMETA IZ REPUBLIKE HRVATSKE ${ }^{88}$}

U hitnom traktu u bolnicu je 9. srpnja 2006. zaprimljen mladić u dobi od 22 godine kojem je dijagnosticirana akutna upala slijepog crijeva. Nakon klinički potvrđene dijagnoze pristupilo se operativnom zahvatu, sljedeći dan u 00,30 sati, i primijenjena je laparaskopska ${ }^{89}$ metoda. $\mathrm{Na}$ kraju operativnog zahvata anesteziolog

85 Za naknadu štete paraplegičaru, ali iz prometne nezgode, vidi odluku VSSl, II Ips-144/2017, od 25. siječnja 2018., ECLI:SI:VSRS:2018:II.IPS.144.2017.

86 VSSl od 1991. vodi evidenciju sudske prakse na način da evidentira pojedinačne predmete a primjeri su javno dostupni u bazi neimovinske štete (NEGM), odnosno u zbirci odluka o naknadi štete u kojima je VSRS odlučivao. Pobliže vidi u odluci II Ips 247/2015, od 5. studenog 2015., ECLI:SI:VSRS:2015:II.IPS.247.2015.

87 U RS je Vlada izradila Poročilo o izvedenih ukrepih iz Projekta Šilih, od 25. svibnja 2018., dostupno na: http://www.mp.gov.si/fileadmin/mp.gov.si/pageuploads/mp.gov.si/ novice/2018/180620_porocilo.VG.pdf, stranica posjećena 12. prosinca 2018. Predmet Šilih detaljnije je analiziran u poglavlju 7.3.

88 Predmet Općinskog suda u Rijeci, neobjavljen, P-943/07, Županijskog suda u Rijeci, Gž881/16, dostupan na: https://sudovi.pravosudje.hr/zsri/img/File/test/presuda\%20i\%20rjesenje. doc i VSRH, Rev-x-848/18 - neobjavljen.

89 Vidi Medicinska enciklopedija, 2. dopunski svezak, Zagreb, Jugoslavenski leksikografski zavod, 1974., str. 355-357. Laparoskopija je minimalno invazivna procedura kojom se u trbušnu duplju ulazi sa rigidnim cijevima, troakarima, kroz koje se može u trbušnu duplju uvesti teleskop s malom kamerom i specijalni laparoskopski kirurški instrumenti. Prethodno se u trbušnu šupljinu upumpava, s posebnim uređajem, ugljik-dioksid i time se formira šupljina u kojoj je moguće izvesti operacije na više intrabdominalnih organa. Kirurg postupak ne vidi direktno nego na posebnom monitoru poput onoga na običnom kućnom računalu. Najčešća operacija je laparoskopska kolecistektomija. Ovom operacijom se uklanja žučni mjehur zajedno sa njenim sadržajem i žučnim kamencima ako su prisutni. Vidi na: https://bs.wikipedia.org/ wiki/Laparoskopija, mrežna stranica posjećena 12. prosinca 2018. 
je zamijetio krvarenje u abdomenu. $\mathrm{U}$ tom se trenutku operativni zahvat konvertira te se čini medijalna laparatomija. ${ }^{90}$ Odmah po otvaranju trbušne šupljine uočena je velika razderotina aorte što je i bio razlog obilnog krvarenja oštećenog. Pregledom su utvrđene i druge unutrašnje povrede nastale instrumentarijem koji se uobičajeno rabi pri laparaskopskoj tehnici. Po operativnom zahvatu nastupile su postoperacijske komplikacije te je nastupilo višeorgansko zatajenje i akutno bubrežno zatajenje, akutni respiracijski distres sindrom sepsa, pneumonija te compartment sindrom ${ }^{91}$ obije potkoljenice. Oštećeni je 18 dana bio u stanju duboke kome i priključen na parate za održavanje života. Cijelo je vrijeme imao visoku tjelesnu temperaturu, liječen jakim lijekovima te mu se na glavi i tijelu, zbog dugog ležanja, razvio dekubitus. Zbog cirkulacijske insuficijencije lijeve potkoljenice amputirana mu je lijeva noga u razini trećine natkoljenice 21 srpnja 2006. Imao je ukupno 29 operacija.

Zbog štete pretrpljene u bolnici oštećeni je zatražio naknadu štete u ukupnom iznosu od 13.045.000,00 kn, ${ }^{92}$ a od toga je za neimovinsku štetu zatražio 7.500.000,00 kn. ${ }^{93}$ Tužbom je kao tužene označio RH i bolnicu označivši ih kao solidarne dužnike. ${ }^{94}$

Prvostupanjskom presudom oštećenom je dosuđen iznos od 2.450.000,00 kn na ime neimovinske štete sa zakonskim zateznim kamatama.

Drugostupanjski sud preinačio je prvostupanjsku presudu, u odnosu na neimovinsku štetu, i tužitelju s tog osnova dosudio $1.380 .000,00 \mathrm{kn}$, sa zateznim kamatama.

Posredno oštećeni (majka, otac i sestra) ustali su tužbom tražeći pravičnu novčanu naknadu neimovinske štete zbog naročito teškog invaliditeta sina odnosno brata.

Prvostupanjski sud je majci i ocu dosudi svakome po $220.000,00 \mathrm{kn}, \mathrm{s}$ kamatama a sestri 75.000,00 kn, s kamatama.

Drugostupanjski sud preinačio je prvostupanjsku presudu i posredno oštećene odbija sa tužbenim zahtjevom.

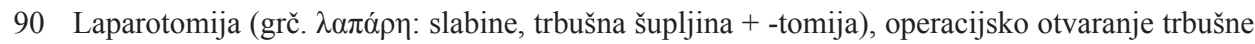
šupljine trbušnim rezom, radi kirurškoga zahvata u trbuhu. Vidi na: http://www.enciklopedija. hr/natuknica.aspx?ID=35416, mrežna stranica posjećena 12. prosinca 2018.

91 Kompartment sindrom, sindrom mišićnih odeljaka reperfuzijski je poremećaj izazvan ishemijskim otokom mišića, zatvorenih u gustom fascijalnom omotaču (najčešće kod podlaktice, potkolenice i butine). Kao posljedica otoka raste subfascijalni (intrakompartmentski) tlak, što dovodi do narušavanja mikrocirkulacije u mišićima i porasta ishemijskog otoka koji napreduje do gangrene na udovima. Ireverzibilna neuromuskularna oštećenja nastaju poslije 12 sati od početka kliničkih manifestacija kompartment sindroma. Stoga su brza i prava dijagnoza kompartment sindroma i dekompresija putem fasciotomije presudne za uspostavljanje normalne cirkulacije i spašavanja ugroženog ekstremiteta od nekroze i amputacije. Vidi na: https://sr.wikipedia.org/sr-el/Kompartment_sindrom, mrežna stranica posjećena 12. prosinca 2018.

92 U radu nećemo razmatrati traženu imovinsku štetu obzirom da u tom dijelu još uvijek traje prvostupanjski postupak. Osim oštećenog naknadu štete zatražili su i posredno oštećeni njegovi roditelji i sestra.

93 Konačni tužbeni zahtjev, u odnosu na neimovinsku štetu, tužitelj je postavio 6. studenog 2015. zatraživši $7.000 .000,00 \mathrm{kn}$.

94 Posredno oštećeni majka, otac i sestra tužili su samo bolnicu za pravičnu novčanu naknadu neimovinske štete. 
VSRH je svojom odlukom preinačio drugostupanjsku odluku na način da je roditeljima dosudio svakome po $170.000,00 \mathrm{kn}, \mathrm{s}$ kamatama. Revizija sestre odbačena je kao nedopuštena zbog visine vrijednosti predmeta spora. ${ }^{95}$

$\mathrm{VSRH}^{96}$ donio je tzv. orijentacijske kriterije za dosudu pravične novčane naknade neimovinske štete. U teoriji se pojavila kritika navedenih kriterija tim više što je 1. siječnja 2006. stupio na snagu novi ZOO/Hrv prema kojem je prihvaćena objektivna koncepcija neimovinske štete kao povrede prava osobnosti. Tako Crnić ${ }^{97}$ zaključuje: ,(...) suđenje u predmetima neimovinske štete zahtijeva primjenu pravnog standarda pravičnost, a ne samo matematiku koja proizlazi iz mehaničke primjene orijentacijskih kriterija.“

\section{ANALIZA PREDMETA}

\subsection{Predmet iz Republike Slovenije}

U predmetu iz RS prijeporno je bilo je li tijekom liječenja počinjena liječnika pogreška $^{98}$ i da li je medicinski zahvat učinjen bez davanja adekvatnog obavještenja pacijentici. Raspravljalo se o tomu je li odgovornost za štetu ugovorna ili izvanugovorna, kao i radi li se o liječničkoj pogrešci ili komplikaciji, ${ }^{99}$ odnosno je li oštećena dobila sva objektivno raspoloživa objašnjenja.

95 Revizija je odbačena iz razloga jer visina pobijanog dijela presude po zahtjevu sestre $(70.000,00$ kn) ne prelazi granični iznos za dopuštenost revizije $(200.000,00 \mathrm{kn}-$ čl. 382. st. 1. t. 1. Zakona o parničnom postupku, S1. 1. SFRJ, br. 4/77, 36/77, 6/80, 36/80, 43/82, 69/82, 58/84, 74/87, $57 / 89,20 / 90,27 / 90,35 / 91$, i NN, br. 53/91, 91/92, 58/93, 112/99, 88/01, 117/03, 88/05, 02/07, 84/08, 96/08, 123/08, 57/11, 148/11, 25/13, 89/14.

96 Kriterije je prihvatio Građanski odjel VSRH, Broj: Su-1331-VI/02 i 1372-11/02, na sjednici održanoj 29. studenoga 2002. Dostupno na: http://www.iusinfo.hr/Appendix/DDOKU_HR/ DDHR20110111N53_5_1.pdf, stranica posjećena 12. prosinca 2018. Orijentacijski kriteriji i iznosi za utvrđivanje visine pravične novčane naknade nematerijalne štete izvorno su objavljeni u Izboru odluka VSRH, br. 1/03., str. 60.

97 Vidi Crnić, I., Značenje orijentacijskih kriterija Vrhovnog suda Republike Hrvatske za dosudu pravične novčane naknade neimovinske štete, Zbornik Pravnog fakulteta u Zagrebu, vol. 62, 5-6/2012., str. 1715-1730.

98 O liječničkoj pogrešci vidi odluke VSS1, II Ips-384/2009, od 19. svibnja 2011., t. 3., ECLI:SI:VSRS:2011:II.IPS.384.2009., II Ips-302/2011, od 26. travnja 2012., ECLI:SI:VSRS:2012:II.IPS.302.2011， t. 12., II Ips-385/2006, od 21. studenog 2008., ECLI:SI:VSRS:2008:II.IPS.385.2006, II Ips-1145/2008, od 28. siječnja 2010., ECLI:SI:VSRS:2010:II.IPS.1145.2008. O razlikovanju između liječničke pogreške i komplikacije vidi kod Mirković, N., Odgovornost za strokovno napako v zdravstvu, magistarska radnja, Nova Gorica, Evropski pravni fakultet u Novoj Gorici, 2011., str. 80-88.

99 O komplikaciji vidi odluke VSS1, II Ips-342/2014, od 22. siječnja 2015., II Ips 342/2014, ECLI:SI:VSRS:2015:II.Ips.342.2014. Vidi i Flis, V., Medicinska napaka, Medicina in pravo, Sodobne dileme, Maribor, 2006., str. 234. Definiciju liječničke greške možemo iščitati negativnom interpretacijom čl. 45. ZZD/Slo. Nadležno ministarstvo u RS osnovalo je komisiju da iznađe definiciju liječničke greške. Vidi na: Ministrstvo za zdravje Republike Slovenije, Zdravstvene napake, dostupno na http://www.mz.gov.si/si/delovna_podrocja/zdravstveno_ varstvo/kakovost_in_varnost_sistema_zdravstvenega_varstva/varnost/zdravstvene_napake/ , stranica posjećena 12. prosinca 2011. 
Što se tiče davanja adekvatnog obavještenja pacijentici ${ }^{100}$ sudovi su, pozvavši se na članak 47. ZZD/Slo, iskazali kako to obavještenje treba biti takvo da se pacijenta obavijesti i o svim mogućim negativnim posljedicama zahvata, a koji nisu ovisni o konkretnim prilikama pacijentice te da obavještenje ne može biti samo generalno. ${ }^{101}$

Iz sudskih predmeta nesporno proizlazi da u suglasnosti koju je oštećena potpisala nije naznačena mogućnost nastanka spinalnog hematoma, odnosno mogućnost nastanka paraplegije kao posljedice spinalne anestezije. Također joj tu mogućnost nije objasnila niti anesteziologinja koja je izvodila spinalnu anesteziju. Dakle, izostanak obavijesti i nastanku tipične, mada iznimno rijetke, komplikacije oštećenoj nije omogućio njezino izražavanje slobodne volje o tome kakovu anesteziju želi odabrati.

Sud, među inim, navodi: Glede na ugotovitve sodišča o kršitvi pojasnilne dolžnosti je zato za razmejitev odgovornosti tožene stranke za nastalo škodo tudi pravno neodločno vprašanje, $v$ koliko meri bi hitrejše prepoznanje zapleta izboljšalo današnje stanje tožnice. Tožena stranka je zaradi odvzema možnosti toženici, da svobodno izbere poseg in posledično tveganje, ki jih bo trpela, za nastalo škodo u celotiodgovorna na pogladi 131. člena OZ.

Zanimljivo je da je sud ${ }^{102}$ o nedavanju adekvatnog obavještenja (informacije) pacijentici obrazložio čak na sedam stranica presude.

Što se tiče liječničke pogreške ${ }^{103}$ sudovi su zauzeli stav da oštećena nije tijekom postupka uspjela dokazati da je pri izvođenju spinalne anestezije došlo do liječničke pogreške kao i da ona nije izvedena nepažljivo. Sud je tako zaključio iz provedenih vještačenja, iskaza svjedoka kao i medicinske dokumentacije. Sud navodi: Sodišče kod odločilno torej $v$ konkretnem primeru izpostavlja, da sta oba izvedenca potrdila trditve tožene stranke, da gre za komplikacijo, ki ni posledica strokovne napake, temveč gre za tipično negativno posledico takšnega posla. Četudi je torej njena pogostost majhna, je zdravstvena ustanova oziroma zdravnik dolžan z njo seznamiti pacienta, predvsem tudi zato, ker je zaplet takšne narave, ga gre za hudo posledico na zdravlje pacienta (v obravnavanem primeru plegija).

Kako je sud donio međupresudu ona ima i neke pravne posljedice na tužbene zahtjeve koje je oštećena naknadno podnosila. Tako je oštećena 2015. zatražila naknadu štete za troškove izgradnje dizala i prilagodbe kupaonice koji zahtjev nije bio zatražen prvotnom tužbom. Sud stoga smatra da je taj dio u zastari upravo zato jer

100 Vidi Pohar, K., Pojasnilna dolžnost zdravnika: obseg pojasnila o tveganjih, Podjetje in delo, 39, 1/2013, str. 146-169.

101 Pri tome se sud pozvao i na pravnu teoriju Bernat, E., Zdravnikova pojasnjevalna dolžnost prikaz iz avstrijskeg prava, Medicina in pravo III, Maribor, Slovensko zdravniško in pravniško društvo v Mariboru, 1995., str. 100, ali i na stav VSS1, II Ips-99/2006, od 16. lipnja 2008., točke 6. i 8., ECLI:SI:VSRS:2008:II.IPS.99.2006.

102 Okružni sud u Ljubljani, P-2135/2003, od 7. listopada 2013., str. 7-14.

103 Sudovi putem vještaka medicinara utvrđuje što je to sadržaj medicinskog standarda u svakom pojedinom slučaju, vidi odluku VSSl, II Ips-342/2014, od 22. siječnja 2015., ECLI:SI:VSRS:2015:II.IPS.342.2014., gdje se povredom medicinskog standarda smatra kada se kod zastoja rada srca nije posumnjalo u pneumotoraks. Sud smatra povredom medicinskog standarda kada je samo liječenje započelo nepravodobno i krivim odabirom lijekova, Viši sud u Ljubljani, I Cp-60/2014, od 4. lipnja 2014., ECLI:SI:VSLJ:2014:I.CP.60.2014. 
nije pokriven međupresudom. ${ }^{104}$

Vezano za pitanje radi li se o ugovornoj ili izvanugovornoj odgovornosti za štetu, sud najprije ukazuje na pravnu teoriju koja zastupa stav da je odnos između pacijenta i liječnika, odnosno zdravstvene ustanove ugovorne naravi. ${ }^{105}$ Nadalje, sud navodi da i sudska praksa zastupa stav da je odnos pacijenta i zdravstvene ustanove ugovorni odnos. No, sudu ostaje dvojba je li ispunjenje dužnosti obavještavanja pacijenta uvjet za valjani način zaključenja ugovora ili je dio ugovornih obveza liječnika, tj. zdravstvene ustanove. Ali navodeći i teoriju ${ }^{106}$ tako i sudsku praksu ${ }^{107}$ sud zauzima stav da informativna privola nema nikakav pravni učinak na zaključenje ugovora. Navodi se kako teorija ugovor između pacijenta i zdravstvene ustanove smatra ugovorom o djelu navodeći da to proizlazi iz odredaba ZZS/Slo (članak 1.) i ZZD/Slo (članak 47.).

U odnosu na dosudu naknade štete posredno oštećenima valja ukazati da su se i sudovi u RS dosta šaroliko odnosili u tumačenju standarda naročito teškog invaliditeta. ${ }^{108}$

Ovdje valja ukazati da iz analize ${ }^{109}$ proizlazi da se u tri predmeta radilo o šteti zbog kršenja obveze davanja obavještavanja pacijentima, dok je u ostalim predmetima razlog za dosudu novčane naknade neimovinske štete bila medicinska pogreška $u$ užem smislu.

\subsection{Predmet iz Republike Hrvatske}

U predmetu iz RH prijeporno je bilo je li oštećeni dao pravno valjani pristanak na laparaskopsku metodu operacije te je li bio pravovaljano obaviješten i o dijagnostičkom i o terapijskom postupku, odnosno jesu li mu objašnjene sve moguće komplikacije pri izvođenju takvog operativnog postupka i je li tijekom operativnog zahvata počinjena pogreška ili se radilo o komplikaciji. ${ }^{110}$

104 O vezanosti međupresude i naknadih zahtjeva vidi VSSl, II Ips-166/2014, od 7. svibnja 2015., t. 8., ECLI:SI:VSRS:2015:II.IPS.166.2014.

105 Pozivaju se na Polajnar Pavčnik, A., Pravo in medicina, Ljubljana, Cankarjeva založba, 1998., str. 92-98; Cigoj, S., Institucije obligacij, Ljubljana, Uradni list, 1989., str. 147.

106 Polajnar Pavčnik, A., op. cit., str. 105; Krušić, M., Pravica do zasebnosti v medicini, Ljubljana, GV Založba, 2010., str. 44.

107 Vidi odluke VSS1, II Ips-65/2012, od 24. siječnja 2013., ECLI:SI:VSRS:2013:II.IPS.65.2012, t. 14., II Ips- 716/2006, od 26. veljače 2009., ECLI:SI:VSRS:2009:II.IPS.716.2006, t. 7., II Ips214/2008, 26. svibnja 2011., ECLI:SI:VSRS:2011:II.IPS.214.2008, t. 7.

108 Vidi VSS1, II Ips-308/2004, od 6. listopada 2005., ECLI:SI:VSRS:2005:II.IPS.308.2004, II Ips418/2006, od 6. studenog 2008., ECLI:SI:VSRS:2008:II.IPS.418.2006, II Ips-1058/2007, od 7. svibnja 2009., ECLI:SI:VSRS:2009:II.IPS.1058.2007, II Ips-458/2008, od 10. ožujka 2011., ECLI:SI:VSRS:2011:II.IPS.458.2008.

109 Vidi bilješku 9. Vidi predmet Šilih protiv Slovenije, zahtjev br. 71463/01, presuda od 9. travnja 2009., dostupna na: http://www2.gov.si/dp-rs/escp.nsf, stranica posjećena 12. prosinca 2018.

$110 \mathrm{O}$ liječničkim pogreškama i komplikacijama pobliže vidi kod Klarić, P., Odgovornost za štete u medicini, u: Medical malpractice, Zagreb, Medicinska naklada, 2008., str. 454-501; Crnić, I., Odgovornost liječnika za štetu, Zagreb, Organizator, 2009., str. 48-67; Radišić, J., op. cit., str. 157-164. VSRH tako smatra da je došlo do povrede medicinskog standarda primjerice, kada liječnik ne provjeri starost pacijenta, Rev-829/06, od 6. rujna 2006., ECLI:HR:VSRH:2006:5913, 
Oštećeni tijekom cijelog postupka tvrdi da od njega nije tražen, niti dobiven, informirani pristanak za operativni zahvat koji mu je učinjen. Prvostupanjski sud tako utvrđuje (...) iz medicinske dokumentacije priležeće spisu nepobitni proizlazi da N.N. nije potpisao pristanak na operativni zahvat, dok je potpisao pristanak za anesteziju. To potvrđuje i drugostupanjski sud navodeći da (...) 1.-vo tužitelj nije potpisao suglasnost za operaciju niti mu je usmeno od strane liječnika prije operacije objašnjen način operativnog zahvata i koji su rizici istoga, kao i moguće komplikacije.

I ako je pacijent potpisao pristanak za anesteziju, nije time potpisao i pristanak za kirurško liječenje.

VSRH u svojoj odluci iznosi jednu zbunjujuću rečenicu (...) da je nakon operacije slijepog crijeva, zbog liječničke pogreške, došlo do komplikacija, zbog čega je tužitelju, tada dvadesetogodišnjak, amputirana lijeva noga u visini donje trećine natkoljenice.

Svi sudovi u RH, koji su odlučivali u sporu, utvrdili su da je jedina pismena suglasnost koju je oštećeni potpisao ona o anesteziji, za druge suglasnosti u medicinskoj dokumentaciji nema traga. Činjenica je da je valjan samo onaj pristanak koji je pacijent dao nakon što je obaviješten o mogućim rizicima postupka, jer samo u toj situaciji nema odštetne odgovornosti bolnice za nastalu neimovinsku štetu. ${ }^{11,112}$

Isključenje protupravnosti medicinskih intervencija na temelju pristanka oštećenika temelji se prema načelu volenti non fit iniuria. ${ }^{113}$ Pristanak pacijenta predstavlja izjavu pacijenta kojom opunomoćuje liječnika da provede određene medicinske radnje. Svrha pristanka pacijenta jest omogućiti mu da razmotri, procijeni i uravnoteži prednosti i nedostatke predloženoga medicinskog tretmana, kako bi racionalno odabrao podvrgnuti se ili odbiti predloženi medicinski tretman. ${ }^{114}$ To nesporno proizlazi iz članka 16. ZZPP/Hrv: Pacijent ima pravo prihvatiti ili odbiti pojedini dijagnostički, odnosno terapijski postupak, osim u slučaju neodgodive medicinske intervencije čije bi nepoduzimanje ugrozilo život $i$ zdravlje pacijenta ili

prebrzi otpust iz bolnice mada infekcija nije bila u cijelosti sanirana, Rev-1180/97 i Rev-859/96, od 5. prosinca 2000., dostupno na: http://www.vsrh.hr, mrežna stranica posjećena 12. prosinca 2018.

111 Vidi odluku Ustavnog suda Republike Hrvatske (dalje: USUD), U-III-3002/2005, od 21. studenog 2007. (NN, br. 133/07).

112 Vidi Pravilnik o obrascima suglasnosti te obrascu izjave o odbijanju pojedinog dijagnostičkog, odnosno terapijskog postupka, NN, br. 10/08. Pravna osnova za dopušteno liječenje i bez pristanka nalazi se u ZZPP/Hrv. Vidi čl. 18. Vidi i Pichler, D., Obaviješteni pristanak u obrascima suglasnosti kojima se prihvaća preporučeni dijagnostički odnosno terapeutski postupak Kliničkog bolničkog centra Osijek i njihova usklađenost s propisima i međunarodnom praksom, Pravni vjesnik, god. 30, 1/2014., str. 89-114.

113 Onome tko pristaje ne čini se nepravda.

114 Ivančić Kačer, B., Informed consent ili informirani pristanak pacijenta na liječenje u hrvatskom pravu . s naglaskom na zaštiti prava liječnika, u: Zborniku Medicina in pravo: Sodobne dileme II, Maribor, Pravna fakulteta Univerze v Mariboru in Zdravniško društvo Maribor, 2010., str. 201-226; Kraljić, S., Informirana privolitev in pravica pacienta do obveščenosti v enotah intezivne medicine (s pregledom evropske sodne prakse), Zbornik radova s međunarodnog kongresa 1. Hrvatski kongres medicinskog prava s međunarodnim sudjelovanjem, 3. do 5. studenoga 2017., Zagreb, str. 216. 


\section{izazvalo trajna oštećenja njegovoga zdravlja. ${ }^{115}$}

Osnovni uvjeti za pristanak obaviještenog pacijenta jesu kompetentnost, obavještavanje, razumijevanje, ${ }^{116}$ dobrovoljnost i pristanak. ${ }^{117}$ Liječenje bez pristanka nije samo građanski delikt, već i kazneno djelo. ${ }^{118}$ Možemo zaključiti da je liječenje protupravno, ako ne postoji pristanak pacijenta, bez obzira na to što je provedeno lege artis. Stoga su sudovi ispravno zaključili da je na oštećenom izvršen kirurški zahvat bez njegovog pristanka. To što je zdravstvena djelatnost u RH korisna ne može biti razlog za opravdanje medicinskog zahvata u tjelesni integritet pacijenta, a pogotovo bez njegove suglasnosti. Drugim riječima samo razlozi medicinske naravi, bez pristanka pacijenta, nisu dovoljno opravdanje za pružanje zdravstvene usluge. ${ }^{119}$ Okolnost da je pacijent dao suglasnost za poduzimanje operativnog zahvata u svrhu liječenje sama po sebi ne oslobađa bolnicu odgovornosti za propuste pri operaciji. ${ }^{120}$ Slobodom pristanka pacijenta na zahvat bavio se i VSRH. ${ }^{121}$

115 Poredbe poradi vidi odredbu čl. 17. Zakona o pravima, obavezama i odgovornostima pacijenata, Službene novine Federacije BiH, broj 40/10. Vidi i Zakon o zdravstvenoj zaštiti Republike Srbije, 2005, poglavlje V Ljudska prava i vrednosti u zdravstvenoj zaštiti i prava pacijenata, čl. 25 do čl. 35, Pravo na informacije čl.27, Pravo na obaveštenje čl. 28, Pravo na slobodan izbor čl. 29; Pravo na samoodlučivanje i pristanak čl. 31-35; vidi izmene i dopune u Sl. glasnik RS, br. 107/05, 72/09 - dr. zakon, 88/10, 99/10, 57/11, 119/12, 45/13 - dr. zakon, 93/14, 96/15, 106/15, 113/17 - dr. zakon i 105/2017 - dr. zakon. Dostupno na: https://www. paragraf.rs/propisi/zakon_o_zdravstvenoj_zastiti.html, mrežna stranica posjećena 12. prosinca 2018. Pobliže vidi Radosavljević, T., Pravna regulacija lekarske delatnosti u Srbiji, master rad, Beograd, Univerzitet u Beogradu, Fakultet organizacionih nauka, Medicinski fakultet, 2014., str. 16-40.

116 O lošim primjerima odnosa liječnika prema pacijentima vidi Štifanić, M., Loša komunikacija i druge liječničke pogreške, JAHR, vol. 4, 7, Rijeka, Katedra za društvene i humanističke znanosti u medicini Medicinskog fakulteta Sveučilišta u Rijeci i Dokumentacijsko-istraživački centar za europsku bioetiku Fritz Jahr Sveučilišta u Rijeci, 2013., str. 301.

117 Pobliže vidi Meisel A, Roth, L. H., What we do and do not know about informed consent, JAMA, 1981., 246, str. 2473-2477. Cit. prema Vučemilo, L., Babić-Bosanac, S., Altarac, S., Borovečki, A., Pristanak obaviještenog pacijenta s posebnim osvrtom na Hrvatsku. Liječnički vjesnik, Zagreb, 136/2014, str. 104. Tako i Jeremić, V., Informirani pristanak: komunikacija između liječnika i bolesnika, Jahr, vol. 4, 7, Katedra za društvene i humanističke znanosti u medicini Medicinskog fakulteta Sveučilišta u Rijeci i Dokumentacijsko-istraživački centar za europsku bioetiku Fritz Jahr Sveučilišta u Rijeci, 2013., str. 528.

118 Ustav RH u čl. 23. st. 1. propisuje: Nitko ne smije biti podvrgnut bilo kakvom obliku zlostavljanja ili, bez svoje privole, liječničkim ili znanstvenim pokusima. U trenutku pisanja ovoga rada kazneni postupak spram operatera u predmetu iz RH još nije okončan.

119 Vidi čl. 1054. st. 2. ZOO/Hrv. Klarić, P., Vedriš, M., Građansko pravo, Zagreb, Narodne novine, 2006., str. 603; Gavella, N., Osobna prava, I. Dio, Predavanja o osobnim pravima uopće, o pravu na tjelesni integritet, na tjelesnu slobodu, na čast i ugled, na privatnost, vlastiti lik, vlastiti glas, osobne zapise i pisma, Zagreb, Pravni fakultet u Zagrebu, 2000., str. 58; Stipković, Z., Protupravnost kao pretpostavka odgovornosti za štetu, Zagreb, Pravni fakultet u Zagrebu, 1991., str. 80-81.

120 Vidi odluku VSRH, Rev-3374/93, od 11. svibnja 1995., dostupno na: http://www.vsrh.hr , stranica posjećena 12. prosinca 2018. Važnošću pristanka pacijenta bavio se USUD, primjerice U-III-3002/2005, od 21. studenog 2007. Vidi u NN, br. 133/07.

121 Oštećeni se nije dužan podvrći rizičnoj operaciji da bi otklonio štetne posljedice povrede koju je zadobio, Vrhovni sud Hrvatske, Gž-510/78, od 6. rujna 1978. Pregled sudske prakse 14/78 
Pacijentov potpis na informirani $\operatorname{pristanak}^{122}$ je forma pravnog akta, koji predstavlja učešće u procesu donošenja medicinske odluke o liječenju. ${ }^{123}$

Na prvom je mjestu pitanje koje sve rizike treba pacijentu priopćiti, da bi se on osposobio za odluku o svome liječenju. U većini europskih zemalja, sudska je praksa usvojila u pogledu dužnosti obavještenja „razuman liječnički standard“, s tim što je sud, u slučaju spora, ovlašten da utvrdi, je li liječnik ispoštovao standard koji je zakonom propisan ili ne. Također je liječnik dužan dati obavještenje, ne čekajući da bude prethodno pitan. Nije prijeporno da obavještenje kao skup mjera koje se planiraju poduzeti, posebno obavještenja o rizicima, spada u jedno od najtežih pitanja sa kojim se liječnik svakodnevno sreće u kliničkoj praksi. Prema članku 8. ZZPP/ Hrv $^{124}$ pacijent ima pravo na potpunu obaviještenost: o svome zdravstvenom stanju, uključujući medicinsku procjenu rezultata i ishoda određenoga dijagnostičkog ili terapijskog postupka, o preporučenim pregledima i zahvatima te planiranim datumima za njihovo obavljanje, o mogućim prednostima i rizicima obavljanja ili neobavljanja preporučenih pregleda i zahvata, o svome pravu na odlučivanje o preporučenim pregledima ili zahvatima, mogućim zamjenama za preporučene postupke, o tijeku postupaka pri pružanju zdravstvene zaštite, o daljnjem tijeku pružanja zdravstvene zaštite, preporučenom načinu života i pravima iz zdravstvenoga osiguranja i postupcima za ostvarivanje tih prava.

Prvostupanjsku sud zaključio je da oštećeni uopće nije obaviješten ${ }^{125}$ koja će se

odluka br. 197.

122 Unutar država članica Europske unije, ali i u državama našeg okruženja pronašli smo samo jedan propis koji izričito traži pismenu formu kao i ZZZ/Hrv, a to je čl. 18. i dalje Zakona o pravima, obavezama i odgovornostima pacijenata Federacije Bosne i Hercegovine, Službene novine Federacije $\mathrm{BiH}$, br. 40/10.

123 Tako Gavella smatra da je pristanak po svojoj prirodi pravni posao, iz čega proizlazi da je za valjanost pristanka potrebno da ispunjava opće pretpostavke valjanosti pravnog posla. S druge strane, Klarić, u skladu s određenjima iz njemačke pravne teorije, smatra da pristanak na medicinski zahvat po svojoj prirodi nije pravni posao jer nije usmjeren na imovinskopravno raspolaganje, pa prema tomu može biti valjan i kada ne ispunjava opće pretpostavke valjanosti pravnog posla. Autori s područja teorije kaznenog prava, npr. F. Bačić, određuju pristanak pacijenta oštećenika kao privatnopravni institut. Slična suprotstavljena stajališta postoje i u njemačkoj i austrijskoj pravnoj književnosti prema kojoj pristanak pacijenta nema karakter pravnog posla, već pristanak na medicinski zahvat predstavlja radnju sličnu pravnom poslu. Švicarsko pravo, s druge strane, pristanak oštećenog na nanošenje štete, pa tako i pristanak pacijenta, smatra jednostranim pravnim poslom. Ovo jer se $u$ švicarskom pravu osobna dobra (život, tjelesni integritet, itd.) određuju objektima građanskopravnih odnosa bez obzira na to što nemaju imovinski karakter. Zbog toga pravni subjekti i mogu raspolagati svojim osobnim dobrima temeljem pravnih poslova. Vidi Nikšić, S., op. cit., str. 368-373.

124 Vidi i Grbčić, Ž., Kakva prava pruža Zakon o zaštiti pacijenata, Informator, br. 5145/2005, str. 40-44; Rušinović Sunara, Đ., Proso, M., Neka pitanja zaštite prava pacijenata u Hrvatskoj, Zbornik radova Pravnog fakulteta u Splitu, god. 42/2005., str. 381-389; Proso, M., Neka pravna pitanja informiranog pristanka u Hrvatskoj legislativi i praksi, Zbornik radova Pravnog fakulteta u Splitu, vol. 43, 2/2006., str. 103-114. Dostupno na: https://hrcak.srce.hr/37819, mrežna stranica posjećena 12. prosinca 2018.

$125 \mathrm{O}$ građanskopravnim posljedicama neinformiranja pacijenata vidi šire Nikšić, S., Građanskopravna odgovornost za liječenje bez pristanka, Građanskopravna odgovornost u medicini, Zagreb, HAZU, 2008., Boila, R. L., Respect for Human Dignity. Ethical and 
vrsta operativnog zahvata nad njim izvesti, u čemu se taj operativni zahvat sastoji i koje su moguće komplikacije navedenoga operativnog zahvata, pa je time postupljeno suprotno odredbi čl. 6. i 16. ZZPP/Hrv.

Zdravstvena djelatnost je zahtjevna profesija te se na njih ima primijeniti članak 10. ZOO/Hrv, kao standard pažnje u obavljanju djelatnosti, gdje je svaki sudionik $\mathrm{u}$ obveznom odnosu dužan u ispunjavanju obveza iz svoje profesionalne djelatnosti postupati s povećanom pažnjom sukladno pravilima struke i običajima.

U konkretnom slučaju takvo postupanje je izostalo. Prvi je propust što oštećenom nije pružena potpuna informacija o načinu i metodi operacije, nadalje nisu mu zatražene potrebne suglasnosti i na kraju u jedinici intenzivne njege propustili su na vrijeme uočiti compartment sindrom.

Sudovi u RH nisu se uopće bavili o problemu ugovorne ili izvanugovorne odgovornosti u konkretnom predmetu. ${ }^{126,127}$ Prvostupanjski sud samo je naveo (...) $d a$

Legal Reflections Regarding the Breach of the Obligation to Inform the Patient, Postmodern Openings, 2013., vol. 4, Iss. 1, March, str. 39. do 54. Dostupno na: http://postmodernopenings. com, mrežna stranica posjećena 12. prosinca 2018. , Dias Pereira, G. A., Existing challenges in medical liability: causation, burden of proof and informed consent. The ever-growing challenge of medical liability: national and European responses, Conference, Strasbourg, 2-3 June 2008, Council of Europe, 2009., str. 141. do146.

126 Ustavni sud je u odluci U-III-3002/2005 izrekao: Bolnica za liječničku grešku odgovara po načelu presumirane krivnje, što znači da ona mora dokazati da je u svemu postupila na način koji je propisan pravilima liječničke struke, te da do štete nije došlo ni zbog obične nepažnje liječnika koji je provodio zahvat. Pri tome je od odlučnog značaja i okolnost je li podnositeljica bila obaviještena o mogućim rizicima punkcije koja je nad njom provedena. Valjan je samo onaj pristanak na dijagnostički postupak koji je pacijent dao nakon što je obaviješten o mogućim rizicima tog postupka. Samo u tom slučaju nema odštetne odgovornosti bolnice za nastalu neimovinsku štetu. “ Nadalje kaže: „Isto tako prvostupanjski sud netočno navodi da se o odgovornosti medicinske ustanove za liječničku grešku odlučuje temeljem načela dokazane krivnje (»nije dokazala krivnju liječnika«), jer se o toj odgovornosti odlučuje prema načelu presumirane krivnje (na liječniku/medicinskoj ustanovi je teret dokaza da je u svemu postupao po pravilima liječničke struke). Praksu VSRH glede presumirane odgovornosti kod odgovornosti bolnica vidi Rev-x-232/08, od 18. veljače 2009., ECLI:HR:VSRH:2009:588, Rev1248/11, od 17. veljače 2015., ECLI:HR:VSRH:2015:1681, Rev-265/12, od 28. veljače 2012., ECLI:HR:VSRH:2012:541, Rev-397/06, od 28. lipnja 2006., ECLI:HR:VSRH:2006:1012, Rev612/08, od 7. prosinca 2010., ECLI:HR:VSRH:2010:7440, Rev-985/07, od 28. studenog 2007., ECLI:HR:VSRH:2007:2317, Rev-x-222/09, od 7. srpnja 2009., ECLI:HR:VSRH:2009:5224, Rev-15/11, od 22. siječnja 2014., ECLI:HR:VSRH:2014:239, Rev-1786/10, od 11. rujna 2012., ECLI:HR:VSRH:2012:2563, Rev-x-1062/13, od 4. lipnja 2014., ECLI:HR:VSRH:2014:27, Rev-x-56/11, od 31. kolovoza 2011., ECLI:HR:VSRH:2011:6818, Rev-x-1129/13, od 19. veljače 2014., ECLI:HR:VSRH:2014:325, Rev-x-564/09, od 23. prosinca 2009., ECLI:HR:VSRH:2009:6755, Rev-1180/08, od 28. listopada 2011., neobjavljena, Rev-x806/2011, od 15. siječnja 2014., ECLI:HR:VSRH:2014:3153.

127 O ugovornoj i izvanugovornoj odštetnoj odgovornosti šire Crnić, I., Odštetna odgovornost liječnika i zdravstvenih ustanova s prikazom sudske prakse, Hrvatska pravna revija, veljača 2009., str. 28-41; Markenstein, F. L., Country Report The Netherlands, u: Zivilrechtliche Regelungen zur Absicherung der Patientenautonomie am Ende des Lebens (Regulations of Civil Law to Safeguard the Autonomy of patients at the End of Their Life), Springer, 2000., str. 741-772; Mujović Zornić, H., Physician's error: medical or legal concept? 29 Med. \& L., 2010., str. 159-169; dostupno na: http://heinonline.org , stranica posjećena 12. prosinca 2018., Radišić, 
stav tužitelja o objektivnoj odgovornosti bolnice ne može se uzeti za točnim jer bolnica ne obavlja opasnu djelatnost koja vodi do objektivne odgovornosti, naime liječenje nije i ne može biti opasna djelatnost jer je nesporno bolest ta koja je izvor opasnosti, a liječnici nastoje otkloniti već postojeću opasnost za zdravlje $i$ život bolesne osobe. Stoga glede odgovornosti bolnice može se govoriti samo o odgovornosti po osnovi krivnje temeljem odredbe čl. 1049 ZOO-a.

Mada je oštećeni u tužbi i tijekom postupka tvrdio da mu je šteta nastala liječničkom pogreškom, sudovi nisu prihvatili njegovo mišljenje. Što je pogreška a što komplikacija i danas je kamen smutnje između pravnika i medicinara. U literaturi koristile su se i koriste se razne definicije liječničke (po)greške. Prema Virchowu ${ }^{128}$ greška je (...) kršsenje opće priznatih pravila umijeća liječenja zbog pomanjkanja dužne pažnje i opreza. Avdjejev ${ }^{129}$ daje ovakvu definiciju: (...) liječnikom pogreškom treba smatrati zabludu liječnika u njegovoj profesionalnoj djelatnosti koja u svojoj osnovi ima nepotpunosti ili nesavršenstvo suvremenih načina istraživanja, objektivne vanjske uvjete kao $i$ neiskustvo samog liječnika. Hansen ${ }^{130}$ daje ovu definiciju: liječnička greška je povreda liječničkog umijeća činjenjem nečega što je nedopustivo ili propuštanjem mjera koje su preporučene. Pejaković131 ističe da je (...) liječnička greška je stručna zabluda bez elemenata nesavjesnosti.

Prema članku 120. ZZZ/Hrv liječnik čini grešku ako ne postupa: (...) prema pravilima zdravstvene struke i moralnim i etičkim načelima.$^{132} \mathrm{U}$ RH mjerilo pažnje za zdravstvene radnike je pažnja dobrog stručnjaka (članak 10. stavak 2. ZOO/Hrv) a to znači povećanu pažnju prema pravilima struke i običajima. Dakle, skrivljeno bi postupao zdravstveni radnik koji bi postupao s pažnjom koje ne bi bila na visini pažnje dobrog stručnjaka.

Komplikacija: ${ }^{133}$ (...) nastaje usprkos medicinski ispravnom $i$ pravodobno provedenom postupku koji je izveden pravilnom upotrebom ispravne opreme i sredstva uz optimalnu organizaciju rada.

Odštetno pravo u RH ne pozna pojam liječnika (po)greška.

Sudovi RH veoma su lapidarno utvrdili i obrazložili izostanak obaviještenosti oštećenog o namjeri medicinskih mjera koje će se poduzeti. Opseg obavještenja o rizicima zavisi o okolnostima konkretnog slučaja. U predmetu iz RH liječnici su trebali oštećenoga upoznati s rizicima koje donosi laparaskopska operacija u odnosu na klasičnu, tako primjerice, da s obzirom na mršavost pacijenta postoji mogućnost

J., Pravna priroda odgovornosti medicinskih poslenika i njihovog odnosa s pacijentima, Pravni život, 9-10/1992., str. 1759-1771; Bollweg, H. G., Defining the extent of (medical) liability, The evergrowing challenge of medical liability: national and European responses, Conference, Strasbourg, 2008.

128 Virchow, R., Gesammelte Abhandlugen aus dem Gebiete der öffentlichen Medizin und der Seuchenlehre, 1. Band, Berlin, Hirschwald, 1879., str. 514.

129 Citirani prema Škavić, J., Zečević, D., Komplikacija i greška - sudskomedicinski pristup u Građanskopravna odgovornost u medicini, Zagreb, HAZU, 2008., str. 23.

130 Loc. cit.

131 Loc. cit.

132 Istovjetno i čl. 2. t. 5. ZL/Hrv.

133 Ibid., str. 25. 
oštećenja krvnih žila, i sl. Kako zahvat na oštećenom očito nije bio hitan ${ }^{134}$ bilo je više nego dovoljno vremena upoznati ga sa svim prednostima i nedostatcima, laparoskopske operacije u odnosu na klasičnu. Naime, kada zahvat nije hitan tada se traži totalno obavještenje, koje mora da obuhvati ne samo krajnje rijetke rizike i moguće neuspjehe zahvata, nego čak i neugodnosti u obliku bolova i sl. ${ }^{135}$

Ovdje ukazujemo da poduzimanje određenog medicinskog postupka, a bez valjanog pristanka pacijenta, znači za liječnika odgovornost ne samo za eventualni slučaj pogreške u liječenju, već odgovornost nastaje i zbog samovoljnog liječenja. Zanimljivo je da tu okolnost tužitelj u predmetu iz RH nije uopće iznosio.

Može se postaviti pitanje čini li se nedavanjem obavještenja pacijentu i liječnička (po)greška? Valja ukazati da liječničku (po)grešku u parnici mora dokazati pacijent dok nepostojanje (po)greške u obavještavanju mora dokazati liječnik, tj. zdravstvena ustanova.

Oštećeni je tijekom parničnog postupka dokazao da je do pogoršanja njegova zdravlja došlo kao posljedica provedenoga medicinskog zahvata. Nadalje, on nije morao dokazivati liječnikovu odgovornost (prema članku 1045. ZOO/Hrv), njegova se krivnja presumira, ali je zato dokazao postojanje uzročne veze između provedenog liječenja i nastale štetne posljedice. Niti sudska vještačenja (u kaznenom i u parničnom postupku) nisu dala decidirani odgovor na pitanje koji je dio medicinskog postupka bio posljedica pogreške, a koji dio je komplikacija. Sudovi su zauzeli stav da se radilo samo o propustu u liječenju u jedinici intenzivnog liječenja.

Ovdje ukazujemo da je drugostupanjski sud dosta hrabro, premda manjkavo obrazloženo, odbio tužbeni zahtjev posredno oštećenih uz obrazloženje: Ukonkretnom slučaju kod 1. - vo tužitelja - koji je brat i sin 2.- go do 4. - to tužitelja, je uslijed štetnog događaja nastupio trajni invaliditet u omjeru $85 \%$, međutim pojavni oblici tog invaliditeta koji se isto očituje u konkretnom slučaju ukazuje na neosnovanost tužbenog zahtjeva 2. - go do 4. - to tužitelja. Naime, tužitelj unatoč naročito teškom invaliditetu može samostalno komunicirati (u stanju je samostalno se kretati uz pomoć ortopedskih pomagala, u stanju je voziti automobil s automatskim mjenjačem), može samostalno obavljati osnovne životne aktivnosti, očuvane su mu spoznajne mogućnosti, kao i mogućnosti valjanog upravljanja svojom voljom, te u takvoj situaciji vanjski pojavni oblici invaliditeta ne pružaju osnov za dosudu pravične novčane naknade

$134 \mathrm{Na}$ operativni zahvat čekalo se od oko 18,00 sati pa sve do 00,30 sati sljedećeg dana.

135 Liječnik nema obveze davanja obavještenja ako je pacijent već obaviješten, ako se odrekne prava na obavještenje i ako postoji medicinska kontraindikacija. 
neimovinske štete zbog naročito teškog invaliditeta bliske osobe. ${ }^{136,137}$

Treba naglasiti da su stranke (neposredno oštećeni) u oba predmeta zahtijevale naknadu štete za tuđu pomoć i njegu, a uopće nisu zahtijevale naknadu štete u obliku novčane rente radi trajno povećanih potreba (čl. 1095. st. 2. ZOO/Hrv). I sudska praksa rijetko može odlučivati o tužbenom zahtjevu za tuđu pomoć i njegu i o zahtjevu za novčanom rentom radi trajno povećanih potreba. ${ }^{138} \mathrm{O}$ tomu da je u praksi prisutan problem razlikovanja ta dva vida naknade štete ukazuje i jedan sudski predmet iz Republike Srbije. ${ }^{139}$

\subsection{Liječnička pogreška i komplikacija, kao povreda ljudskih prava}

Pred Europskim sudom za ljudska prava (ESLJP) ${ }^{140}$ bilo je više predmeta iz RS i RH vezanih za štete u medicini. Katić ${ }^{141}$ navodi da su predmeti protiv RH koji su se pred ESLJP-om pojavili pokazali da RH nije imala pravni i sustavni odgovor na pitanje kako prepoznati, utvrditi, istražiti, a onda i adekvatno sankcionirati situacije u kojima je postojala sumnja da je smrt pacijenta nastupila zbog liječničke pogreške. Nadalje navodi kako se kao posebno pitanje u tim predmetima pojavio problem objektivnosti vještačenja jer se pokazalo da često liječnici iz iste ustanove, bolnice ili medicinskog

136 Po tom pitanju i praksa VSRH je dosta šarolika, vidi primjerice Rev-1180/97, od 5. prosinca 2000., dostupno na: http://www.vsrh.hr, mrežna stranica posjećena 12. prosinca 2018., Rev-2103/99, od 3. prosinca 2002., ECLI:HR:VSRH:2002:4859 , Rev-1194/11-2 od 24. travnja 2012., ECLI:HR:VSRH:2015:3703, Rev-x- 1099/13, od 8. siječnja 2014., ECLI:HR:VSRH:2014:2263, Rev-X-980/11, od 22. veljače 2012., ECLI:HR:VSRH:2012:7709. USUD je u odluci, U-III-576/2000, od 24. siječnja 2007., iskazao: (...) pri ocjeni postoji li naročito teški invaliditet kao osnova za dosuđenje pravične novčane naknade treba utvrđivati ne samo postotak invaliditeta, već i pojavne oblike (vanjske, trajne i stalne manifestacije) kroz koje se taj invaliditet očituje, jer spomenuti elementi tek u svojoj ukupnosti predstavljaju temelj za procjenu pripada li posrednom oštećeniku pravo na pravičnu novčanu naknadu.

137 Širi prikaz prakse VSRH vidi kod Jelušić, D., Pravo na pravičnu novčanu naknadu u slučaju osobito teškog invaliditeta bliske osobe, Novi Informator, br. 5690/2008, str. 8-11 i 5691/2008, str. 11-12.

138 U dostupnoj sudskoj praksi RH nismo uspjeli pronaći takav tužbeni zahtjev, odnosno pravorijek.

139 Vidi presudu Apelacionog suda u Beogradu, Gž-128/17, od 10. veljače 2017., kao i presudu Vrhovnog kasacionog suda, Rev-1266/17, od 13. srpnja 2017., citirano prema Borovac, J., Novčana renta zbog trajnog povećanih medicinskih potreba u: Zborniku XXI Međunarodnog naučnog skupa Odgovornost za štetu, naknada štete i osiguranje, Institut za uporedno pravo, Udruženje za odštetno pravo, Beograd - Valjevo, Pravosudna akademija, 2018., str. 121-130.

140 ESLJP je međunarodni sud ustrojen 1959., sa sjedištem u Strasbourgu. Njegova je nadležnost odlučivati o pojedinačnim ili međunarodnim zahtjevima koji se odnose na povredu građanskih i političkih prava sadržanih u Europskoj konvenciji za zaštitu ljudskih prava i temeljnih sloboda (dalje: EKZLJPTS, NN, MU, br. 18/97, 6/99, 14/02, 13/03, 9/05, 1/06, 2/10). Zadaća ESLJP-a je osigurati da države poštuju prava i jamstva predviđena EKZLJPTS-om. U trenutku kada utvrdi da je neka država povrijedila jedno ili više tih prava i jamstava, EKZLJPTS donosi presude koje su obvezujuće za svaku državu i dovode do toga da dotične zemlje imaju obvezu postupati po njima i mijenjati svoje zakonodavstvo i administrativnu praksu u velikom broju područja kako se slične povrede ne bi ponavljale u budućnosti.

141 Katić, N., Liječnička pogreška kao povreda ljudskih prava, Sarajevo, Fondacija Centra za javno pravo, 2008., dostupno na: http://www.fcjp.ba/templates/ja_avian_ii_d/images/green/ Nikolina_Katic.pdf, mrežna stranica posjećena 12. prosinca 2018. 
fakulteta vještače o (ne)savjesnosti liječnika i o postupanju svojih kolega.

U RH ne postoji sustavna evidencija o tomu je li zbog liječničke pogreške došlo do smrti ili narušavanja zdravlja, odnosno drugih teških posljedica. ${ }^{142}$

EKZLJPTS ne sadrži pravo na zdravlje kao konvencijsko pravo, ali se ono iskristaliziralo u postupke vođenim pred ESLJP-om. ${ }^{143}$ Šilih. ${ }^{145}$

Predmet, u odnosu na $\mathrm{RH}$, je predmet Bajić, ${ }^{144}$ dok je za RS važan predmet

U predmetu Bajić radi se o smrti sestre podnositelja zahtjeva, zbog liječničke pogreške. Liječnici su kazneno i disciplinski prijavljeni u RH. ESLJP je u ovom predmetu utvrdio kako kazneni postupak koji se vodio pred domaćim tijelima nije zadovoljio jamstva članka 2. EKZLJPTS. Sud smatra zahtjev da postupak, kojim se može utvrditi uzrok smrti pacijenata u skrbi medicinskih stručnjaka, mora biti vođen tako da se osigura neovisnost nalaza i mišljenja vještaka koji u njemu sudjeluju. ESLJP je utvrdio kako se vještaci koji su sudjelovali u kaznenom postupku protiv liječnika u predmetu Bajić nisu mogli smatrati objektivno nepristranima, budući da su bili profesori na istom Medicinskom fakultetu, odnosno zaposlenici istog $\mathrm{KBC}$-a, kao i liječnik čiji rad su vještačili. Sud zaključuje: ,, (...) s obzirom na takvu pozadinu [predmeta], Sud nalazi da domaći sustav u cjelini, suočen s predmetom u kojem se radi o navodnom nesavjesnom liječenju koje je dovelo do smrti podnositeljeve sestre, nije dao odgovarajući i pravodoban odgovor u skladu s postupovnim obvezama države iz članka 2. Konvencije. Gotovo istovjetno ESLJP zaključio u predmetu Kudra: ${ }^{146}$ (...) kako domaći sustav, suočen s predmetom nenamjernog lišenja života, nije dao djelotvoran i brz odgovor u skladu s postupovnim obvezama države iz članka 2. Konvencije.

142 Sukladno iznesenom niti Hrvatska liječnička komora nema evidencija o disciplinskim postupcima koji se vode poradi liječnike pogreške. Nažalost niti sudovi ne vode takove evidencije. Nema ih niti državno odvjetništvo.

143 Vidi primjerice Thematic Report: Health - related issues in the case-law of the European Court of Human Rights. Dostupno na: https://www.echr.coe.int/Documents/ Research_report_health.pdf, stranica posjećena 12. prosinca 2018. Vidi odluke ECHR, Trocellier protiv Francuske, br. 75725/01, § 4, dostupno na: https://hudoc.echr.coe.int/ fre\#\{\%22fulltext $\% 22:[\% 22$ trocellier $\% 22], \% 22$ itemid $\% 22:[\% 22001-77737 \% 22]\}, \quad$ Kudra protivHrvatske, 13904/07, presudaod 18.12.2012, §100.Dostupnona:https://hudoc.echr.coe.int/ fre\#\{\%22fulltext \%22:[\%22besen\%22],\%22itemid\%22:[\%22001-112140\%22]\}, Konczelska protiv Poljske, br. 27294/08, odluka od 20. 09. 2011, §35. Dostupno na: https://hudoc.echr.coe. int/eng\#\{\%22fulltext\%22:[\%22Konczelska\%22],\%22itemid\%22:[\%22001-106894\%22]\}, mrežne stranice posjećene 12. prosinca 2018.

144 Bajić protiv Hrvatske, zahtjev br. 41108/10, presuda od 13. 11. 2012. Dostupno na: $\quad$ https://hudoc.echr.coe.int/eng\#\{\%22fulltext $\% 22:[\% 22 \backslash \% 22 \mathrm{CASE} \% 20 \mathrm{OF} \% 20$ BAJI\%C4\%86\%20v.\%20CROATIA $\% 22 \% 22], \% 22$ sort $\% 22:[\% 22 \mathrm{kpdate} \% 20$ Des cending \% 22 ], \% 22 respondent \% 22 : [ \% 22 H R V \% 22 ], \% 22 itemid\%22:[\%22001-114490\%22]\}, mrežna stranica posjećena 12. prosinca 2018.

145 Vidi bilješku 127.

146 Vidi bilješku 143. Vidi i predmet predmetu Bilbija $i$ Blažević protiv Hrvatske, zahtjev br. 62870/13, presuda od 12. 01. 2016. Dostupno na: https://hudoc.echr.coe.int/ eng\#\{\%22fulltext\%22:[\%22bilbija\%22]\}, mrežna stranica posjećena 12. prosinca 2018. 
U predmetu Šilih ${ }^{147}$ sin podnositelja zahtjeva umro je u bolnici 19. svibnja 1993. od anafilaktičkog šoka, koji je vjerojatno nastupio kao rezultat alergijske reakcije na jedan od lijekova koji mu je prepisao dežurni liječnik pri pokušaju da izliječi urtikariju zbog koje se javio u bolnicu. U trenutku smrti imao je 20 godina. Podnositelji zahtjeva su 1993. podnijeli kaznenu prijavu protiv dežurnog liječnika zbog nesavjesnog liječenja, ali je ta prijava odbačena zbog nedostatka dokaza. Dana 1. kolovoza 1994., pošto je stupila na snagu Europska konvencija za zaštitu ljudskih prava u Sloveniji, podnositelji zahtjeva su iskoristili svoje pravo na temelju slovenskog Zakona o kaznenom postupku da kao oštećena strana postupe kao tužitelji i podnesu zahtjev za pokretanje kaznene istrage. Ta je istraga ponovo otvorena 26. travnja 1996. i 28. veljače 1997. podignuta je optužnica. Slučaj je dva puta vraćan radi dodatne istrage prije nego što je 18. listopada 2002. obustavljen kazneni postupak, ponovo uz obrazloženje da nema dovoljno dokaza. Podnositelji zahtjeva su se žalili, ali bez uspjeha. U međuvremenu su 6. srpnja 1995. podnositelji zahtjeva poveli i građansku parnicu protiv bolnice i liječnika. Prvostupanjski postupak, koji je mirovao između listopada 1997. i svibnja 2001., okončan je tako što je tužba odbačena 25. kolovoza 2006., više od 11 godina poslije inicijalnog pokretanja postupka. Tijekom tog razdoblja u ovom slučaju sudilo je šest sudaca. Poslije toga podnositelji zahtjeva su uložili žalbu na presudu, kao i žalbu iz formalnih razloga, ali nijedna od tih žalbi nije riješena u njihovu korist.

U presudi od 28. lipnja 2007. ESLJP je jednoglasno presudio da je prekršen članak 2. EKZLJPTS-a u svezi s odsustvom djelotvornoga pravnog postupka kojim bi se ustanovio uzrok smrti u bolnici sina podnositelja zahtjeva. ESLJP je zaključio i da nacionalne vlasti nisu, pri odlučivanju u predmetu pokrenutom na temelji prijave podnositelja zahtjeva koja se odnosila na smrt njihova sina, iskazale onu vrstu pažnje koju nalaže članak 2. EKZLJPTS-a. Dakle, time je narečena odredba prekršena zbog neučinkovitosti slovenskog pravosuđa koje nije ustanovilo uzrok smrti sina podnositelja zahtjeva, a niti je ustanovio tko je odgovoran za smrt.

\section{ZAKLJUČNO}

Zakonodavci u većini zemalja nisu donijeli precizne norme oko šteta u zdravstvu, pa se one razmatraju unutar općih pravila o odgovornosti - naknadi štete. Stoga je polje slobodne sudske ocjene ostalo jako široko, a posljedica toga je šarolikost sudske prakse. ${ }^{148}$ Niti u Europskoj uniji ne postoje jedinstvene metode vrednovanja

147 Pobliže vidi kod Jurkovič, M., Zdravstvena napaka - pravni in etični vidiki odgovornosti zdravnika v Republiki Sloveniji, magistarski rad, Evropska Pravna fakulteta v Novi Gorici, Nova Gorica, 2013., str. 45-48. Predmet je u RS bio jako medijski zastupljen vidi http://web. vecer.com/portali/vecer/v1/default.asp?kaj=3\&id=2009041005424060, http:/www.dnevnik.si/ kronika/1042307779, http://www.dnevnik.si/kronika/1042416803, https://www.demokracija. si/slovenija/zgodbe/11355-stara-gregorja-iliha-e-vedno-ieta-pravico, http://www.delo.si/ clanek/43784, mrežne stranice posjećene 12. prosinca 2018.

148 Pobliže vidi kod Szoeloesy, P., Tissot, C.R., L'evaluation du dommage resultant de l'invalidité dans divers pays européens, Zürich, Schulthess, 1974., str. 10. 
neimovinske štete, odnosno ocjene njezinih posljedica i visine naknade. ${ }^{149}$ I medicinska su vještačenja i u parničnim i kaznenim postupcima neujednačena. ${ }^{150}$

Zakonodavac u RH mora početi razmišljati ili da dopuni ZOO/Hrv ili ZZPP/ Hrv odredbama o ugovoru o zdravstvenoj usluzi. Ovdje možemo samo podržati de lege ferenda prijedloge Nikšića ${ }^{151}$ koji daje vrlo dobar prijedlog teksta o odredbama ugovora o zdravstvenoj usluzi koji bi trebalo ugraditi u zakon.

U RS i RH prevladava stav da je osnova odgovornosti zdravstvenih radnika subjektivna na temelju presumirane krivnje. Teorija u $\mathrm{RH}^{152}$ zastupa stav da bi se tužitelju (oštećenom) trebalo prepustiti odluku po kojoj osnovi će tražiti naknadu štete od zdravstvene ustanove. ${ }^{153}$ No, dok u sudskoj praksi RS prevladava stav da se radi o šteti iz ugovornog odnosa ${ }^{154} \mathrm{u}$ RH nema o tomu decidiranog stava VSRH.

Nadalje, dok sudska praksa u RH nema dvojbi pripada li pravo na naknadu neimovinske štete i posredno oštećenima (primjerice unuku) ${ }^{155}$ u sudskoj praksi RS još uvijek o tome nema jedinstvenog stava. ${ }^{156,157}$ Većinom se zauzima stav da je krug osoba kojima se može dosuditi neimovinska šteta zatvoren. ${ }^{158}$ Pravna teorija u $\mathrm{RS}^{159}$ smatra da je odredba članka 179. OZ/Slo apstraktna i pravni standard kojega upravo

149 Pobliže vidi kod Ćurković, M., Europa neujednačena u određivanju šteta, Svijet osiguranja br. 8/2006., str. 38-42; id., Repozicioniranje neimovinske štete u nekim europskim zemljama, u: Naknada neimovinske štete (pravno-medicinski okvir), Zagreb, Inženjerski biro, 2009., str. 121-137.

150 Pokušaj ujednačavanja u RH nalazimo primjerice, kod Zečević, D., Škavić, J., Osnove sudske medicine za pravnike, Zagreb, Barbat, 1996., str. 281-289.

151 Nikšić, S., op. cit., str. 490-504.

152 Vidi Klarić, P., op. cit., str. 385.

153 ZOO/Hrv u čl. 349. propisuje: Ako odredbama ovog odsjeka (radi se o odsjeku 5 - op. a.) nije drukčije propisano, na naknadu ove štete na odgovarajući se način primjenjuju odredbe ovoga Zakona o naknadi izvanugovorne štete.

154 Vidi odluke VSS1, II Ips-342/2014, od 22. siječnja 2015., ECLI:SI:VSRS:2015:II.IPS.342.2014, II Ips-207/2015, od 14. siječnja 2016., ECLI:SI:VSRS:2016:II.IPS.207.2015.

155 Praksa VSRH je još u razdoblju važenja ZOO/91 unuku priznavala pravo na naknadu neimovinske štete zbog gubitka bake, primjerice Rev-259/85, od 20. svibnja 1985., iz arhive autora.

156 VSSl je u jednom pravnom mišljenju baki priznao pravo na naknadu neimovinske štete radi smrti unuka koji je s njom živio u zajedničkom domaćinstvu, pravno mišljenje sjednice VSSl, od 21. i 22. prosinca 1992., Poročilo VSS1, 2/92.

157 Vidi odluku VSS1, II Ips-183/2015, od 3. prosinca 2015., ECLI:SI:VSRS:2015:II.IPS.183.2015.

158 Vidi odluke VSS1, II Ips-591/2008, od 24. lipanj 2009. , ECLI:SI:VSRS:2009:II.IPS.591.2008, II Ips-470/2009, od 8. srpnja 2009., ECLI:SI:VSRS:2009:II.IPS.470.2009.

159 Možina, D., Nepremoženjska škoda zaradi izgube počitnic: Leitner pri nas doma; Podjetje in delo, št. 1/14, Ljubljana, 2014., str. 41 navodi: „Nepremoženjske pravne dobrine so $v$ slovenskem pravu na splošno priznana dobrina. Iz njihovega položaja v ustavni hierarhiji pravnih dobrin, ki je načeloma višji od položaja premoženja, bi lahko sklepali, da je takšno tudi njihovo odškodninsko varstvo, ki ga zagotavlja obligacijsko pravo. Vendar pa, če sledimo zakonu, ni čisto tako: medtem ko načeloma vsak poseg $v$ premoženje pomeni priznano premoženjsko škodo, so pravno priznane le tiste oblike nepremoženjske škode, ki jih opredeljuje zakon. « Božič Penko, A., Razmislek in sodna praksa Vrhovnega sodišča o nekaterih aktualnih vprašanjih odškodninskega prava v zvezi z nepremoženjsko škodo, Ljubljana, Pravni letopis Inštituta za primerjalno pravo, 2016., str. 69. 
sud treba tumačiti u konkretnom sporu. Takav stav je čak prihvaćen u nekim odlukama VSS1. ${ }^{160}$

Svakako je preporuka sudovima u RS da se u tumačenju pravnih odredbi OZ/ Slo u naknadi neimovinske štete posredno oštećenima više drže ciljnog (teleološkog) tumačenja odredbe, a ne isključivo gramatičkog. ${ }^{161}$ Također se nadamo da će sudovi u RH zadržati i unaprijediti svoj način širokog tumačenja kruga posredno oštećenih osoba, a što će pokazati praksa u tumačenju istospolnih zajednica bilo one registrirane ili neregistrirane.

Konačno pridružujemo se stajalištu Hallera ${ }^{162}$ da se profesionalna odgovornost liječnika mora sagledati iz perspektive deset pojmova: stručnosti, povjerenja, odnosa između sudionika, kvalitete u pružanju zdravstvene zaštite, ostvarivosti, ekonomičnosti, prihvaćene znanstvene misli, odsutnosti sukoba interesa i same stručne odgovornosti.

Dvije stvari ispunjavaju mi dušu sve većim divljenjem i strahopoštovanjem: zvjezdano nebo iznad mene i moralni zakon u meni.

E. Kant, Kritika praktičnog uma

\section{LITERATURA}

1. Adams, David Carl, Consent to medical treatment of a minor under the Family Code, Baylor L. Rev., 27/1975, str. 319-330.

2. Bagić, Snježana, Informirani pristanak u sudskoj praksi, Zbornik radova, 2. Hrvatski simpozij medicinskog prava, Vodice, 2016., str. 255-277.

3. Balažic, Jože i dr., Zakon o pacientovih pravicah (ZPacP) skomentarjem. Ljubljana, GV Založba, 2009.

4. Barbić, Jakaša i dr., Naknada štete u primjeni novog Zakona o obveznim odnosima, Zagreb, Narodne novine, 2005.

5. Baretić, Marko, Pojam i funkcije neimovinske štete prema novom Zakonu o obveznim odnosima, Zbornik Pravnog fakulteta u Zagrebu, vol. 56, Posebni broj, 2006., str. 461500.

6. Baümann, Jürgen, Strafrecht, Allgemeiner Teil, 6th ed., 1974.,

7. Bedoya Bergua, Francisco, Žnidaršič, Viktorija, García San José, Daniel, Régimen jurídico de la investicagión biomédica en Andalucía enel marco de la legislación nacional e internacional, Sevilla, Laborum, 2009.,

8. Bevanda, Marko, Ugovor između liječnika i pacijenta, Zbornik Pravnog fakulteta u Rijeci, vol. 26, 1/2005, str. 307-338.

9. Bevanda, Marko, Čolaković, Maja, Pravo pacijenta na obaviještenost i pristanak i pravne posljedice liječenja bez pristanka pacijenta, Zbornik radova Aktualnosti građanskog i trgovačkog zakonodavstva i pravne prakse 7/2009., str. 200-202.

10. Boilặ, Rodica Lacrima, Respect for Human Dignity. Ethical and Legal Reflections Regarding the Breach of the Obligation to Inform the Patient, Postmodern Openings, 2013., vol. 4, Iss. 1, March, str. 39-54. Dostupno na: http://postmodernopenings.com ,

160 Primjerice odluka II Ips-409/2009, od 18. veljače 2010., ECLI:SI:VSRS:2010:II.IPS.409.2009.

161 Vidi Božič Penko, A., op. cit., str. 72-73.

162 Haller, H., Medicinski pogled na liječničku odgovornost, u Građanskopravna odgovornost u medicini, Zagreb, HAZU, 2008., str. 20. 
11. Bollweg, Hans Georg, Defining the extent of (medical) liability, The ever-growing challenge of medical liability: national and European responses, Conference, Strasbourg, 2008.

12. Bošković, Zvonimir, Prava pacijenata na primjerenu obaviještenost i odlučivanje, Informator, br. 5343, od 21. svibnja 2005.

13. Božič Penko, Ana, Razmislek in sodna praksa Vrhovnega sodišča o nekaterih aktualnih vprašanjih odškodninskega prava v zvezi z nepremoženjsko škodo, Ljubljana, Pravni letopis Inštituta za primerjalno pravo, 2016.

14. Burkle, M. Christopher et al., Physician perspectives and compliance with patient advance directives: the role external factors play on physician decision making, BMC Medical Ethics 2012, str. 13-31. Dostupno na: http://www.biomedcentral.com/1472-6939/13/31, posjećeno: 18. prosinca 2018.

15. Callens, Stefaan, Medical Civil Liability in Belgium. Four Selected Cases, European Journal of Health Law, 1/2003, str. 115-133.

16. Cantrell, Crispin, A Physician's Liability for Experimental Procedures, Med Law, 3/1984, str. 339-344.

17. Ceković Vuletić Simonida, Medicinsko pravo, Beograd, Institut društvenih nauka, 1998.

18. Crnić, Ivica, Naknada štete, Zagreb, Organizator, 1995., str. 165-169.

19. Crnić, Ivica, Parnični postupak i naknada štete, Zagreb, Organizator, 2008.

20. Crnić, Ivica, Odštetna odgovornost liječnika i zdravstvenih ustanova s prikazom sudske prakse, Hrvatska pravna revija, veljača 2009., str. 28-41.

21. Crnić, Ivica, Značenje orijentacijskih kriterija Vrhovnog suda Republike Hrvatske za dosudu pravične novčane naknade neimovinske štete, Zbornik Pravnog fakulteta u Zagrebu, vol. 62, 5-6/2012., str. 1715-1730.

22. Čizmić, Jozo, Pravo pacijenata na obaviještenost, s posebnim osvrtom na zaštitu tajnosti podataka o zdravstvenom stanju pacijenta, Zbornik Pravnog fakulteta Sveučilišta u Rijeci, vol. 29, 1/2008, str. 227-275.

23. Ćurković, Marijan, Europa neujednačena u određivanju šteta, Svijet osiguranja, 8/2006.,

24. Ćurković, Marijan, Repozicioniranje neimovinske štete u nekim europskim zemljama, u: Naknada neimovinske štete (pravno-medicinski okvir), Zagreb, Inženjerski biro d.d., 2009., str. 121-137.

25. Ćurković, Marijan, Talijanski sustav naknade štete zbog povrede prava na život i zdravlje, Zbornik radova sa 18. savjetovanja o obradi i likvidaciji međunarodnih automobilskih šteta, Opatija, 2010.

26. Ćurković, Marijan, Talijanski sustav naknade neimovinske štete, Zbornik Pravnog fakulteta u Zagrebu, vol. 62, 5-6/2012., str. 1579-1598.

27. Damaška, Marjan, Neki krivičnopravni aspekti liječničkih zahvata, Hrestomatija hrvatskog medicinskog prava, Zagreb, Pravni fakultet, 2016., str. 72-80.

28. De Bord, Jessica, Informed Consent, dostupno na: https://depts.washington.edu/bioethx/ topics/consent.html, posjećeno: 18. prosinca 2018.

29. De Cruz, Peter, Comparative Healthcare Law, Cavendish Publishing, 2000.

30. De Palma, A., Conoscenza, errori, comunicazione con il paziente e consenso consapevole (Knowledge, mistakes, communication with patients and informed consent), Italian Journal of Medicine, 2013., 3(1), str. 67-71.

31. Deutsch, Eerwin, Medizinrecht-Arztrecht, Arztneimittelrecht, Medizinprodukterecht und Transfusionsrecht, Berlin, 2003.

32. Deutsch, Erwin, Spickhoff, Andreas, Medizinrecht, 6. Auflage, Berlin, Heidelberg, 2008.,

33. Dias Pereira, G. André, Existing challenges in medical liability: causation, burden of proof and informed consent. The ever-growing challenge of medical liability: national and European responses, Conference, Strasbourg, 2-3 June 2008, Council of Europe, 2009., str. 141-146. 
34. Dickens, M. Bernard, Patients' Interests and Clients' Wishes: Physicians and Lawyers in Discord, L. Med. \& Health Care, 1987-1988, 15, str. 110-117.

35. Drobac, A. Jennifer, Goodenough, R. Oliver, Exposing The Myth Of Consent, Indiana health Law Review, vol. 12, 2/2015, str. 471-531. Dostupno na: https://journals.iupui.edu, posjećeno 18. prosinca 2018.

36. Elliott, Carl, Patients doubtfully capable or incapable of consent, Kuhse, H., Singer, P. (ed.), A Companion to Bioethics, 2001, str. 452-462.

37. Gavella, Nikola, Osobna prava. I. dio, Zagreb, Pravni fakultet Sveučilišta u Zagrebu, 2000.

38. Gazdek, Davorka, Informirani pristanak: korijeni, svrha, primjena i ograničenja, Split, Pravni fakultet u Splitu, 2013.

39. Geerds, Friedrich, Einwilligung und Einverständnis des Verletzten, 1953.,

40. Gorenc, Vilim, et alt., Komentar Zakona o obveznim odnosima, Zagreb, RRIF, 2005.

41. Haller, Herman, Medicinski pogled na liječničku odgovornost, u Građanskopravna odgovornost u medicini, Zagreb, HAZU, 2008.

42. Hallinan, P. Zahary et al., Barriers to Change in the Informed Consent Process, A Systematic Literature Review, May-June 2016, vol. 38, iss. 3. Dostupno na: http://www. thehastingscenter.org/, posjećeno 18. prosinca 2018.

43. Hartman, Kurt M., Liang, A. Bryan, Exception to Informed Consent in Emergency Medicine, Hospital Physician, 1999., 35, str. 53-59. Dostupno na: http://www.turnerwhite.com/pdf/hp_mar99_emergmed.pdf, posjećeno: 18. prosinca 2018.

44. Hofmann Johanes, Ausgewählte Probleme der Eigenmächtigen Heilbehandlung im Rettungsdienst, 2017., dostupno na: https:/www.oegern.at/wp/wp-content/uploads/, 18. prosinca 2018.

45. Ivančić-Kačer, Blanka, Informed consent ili informirani pristanaka pacijenta na liječenje u hrvatskom pravu (s naglaskom na zaštiti prava liječnika), Pravo i porezi, 6/2009., str. 10-22.

46. Jefford, Michael, Moore, Rosemary, Improvement of informed consent and the quality of consent documents, Lancet Oncol, 2008., 9, 5, str. 485-493.

47. Jeremić, Vida, Informirani pristanak: komunikacija između liječnika i bolesnika, JAHR, vol. 4, 7/2013, str. 525-533.

48. Juhart, Miha et al., Uvod v civilno pravo, Ljubljana, Uradni list, 2016.

49. Jurkovič, Margerita, Zdravstvena napaka - pravni in etični vidiki odgovornosti zdravnika v Republiki Sloveniji, magistarski rad, Nova Gorica, Evropska Pravna fakulteta v Novi Gorici, 2013.

50. Kennedy, I., Grubba, A., Medical Law, London, 2000.

51. Klarić, Petar, Odštetno pravo, Zagreb, Narodne novine, 2003.

52. Klarić, Petar, Vedriš, Martin, Građansko pravo, IX izdanje, Zagreb, Narodne novine, 2006.

53. Koh, L. K., Doctrine Of Consent In Criminal Law, Malaya L. Rev. 9/1967, str. 181-201.

54. Korošec, Damjan, Pravice zdravnikov v Sloveniji in Evropi (osebnostnopravni vidik) Physicians' Rights In Slovenia and Europe (From The Standpoint Of The Law Of Personal Rights), Zdravstveni vestnik, 75/2006, str. 645-651.

55. Kraljić, Suzana, Informirana privolitev in pravica pacienta do obveščenosti $v$ enotah intezivne medicine (s pregledom evropske sodne prakse), Zbornik radova s međunarodnog kongresa 1. Hrvatski kongres medicinskog prava s međunarodnim sudjelovanjem, 3-5. studenoga 2017., str. 213-226.

56. Laufs, Adolf, Uhlenbruck, Wilhelm, Handbuch des Arztrechts, 3. Auflage, München, 2002.

57. Leischner, Lenzhofer et al., Medical law in Austria, Kluwer Law Internacional, 2011.

58. Makary, Martin A., Daniel, M., Medicial error - third leading cause of death in USA, BMJ, 2016.; 353 i 2139. 
59. Markenstein, F. L., Country Report The Netherlands u Zivilrechtliche Regelungen zur Absicherung der Patientenautonomie am Ende des Lebens (Regulations of Civil Law to Safeguard the Autonomy of patients at the End of Their Life), Springer, 2000., str. 741772.

60. Matijević, Berislav, Kvantitativno ograničenje naknade neimovinske štete kod osiguranja od automobilske odgovornosti - primjeri iz prakse Suda Europske unije, Hrvatska pravna revija, 9-10/2018.

61. Mihut, Alexandru, The Respect for Human Dignity Throughout Life as Reflected in the New Civil Code, Societate şi Politică, 2011., 5(9), str. 67-88. Dostupno na: http://socpol. uvvg.ro/image.

62. Možina, Damjan, Nepremoženjska škoda zaradi izgube počitnic: Leitner pri nas doma; Podjetje in delo, 1/14, Ljubljana, 2014.

63. Mujović Zornić, Hajrija, Petrović, Zdravko, Odgovornost zdravstvenih ustanova za štete kao posledice lečenja (Responsibility of medical institutions for damages resulting from treatment), Vojnosanitetski Pregled, 2012., 69(8), str. 692-699.

64. Mujović Zornić, Hajrija, Physician's error: medical or legal concept?, 29 Med. \& L., 2010., str. 159-169., dostupno na: http://heinonline.org.

65. Nikšić, Saša, Ugovor o zdravstvenoj usluzi, doktorska disertacija, Zagreb, Pravni fakultet Sveučilišta u Zagrebu, 2007.

66. Nikšić, Saša, Građanskopravna odgovornost za liječenje bez pristanka, Građanskopravna odgovornost u medicini, Zagreb, HAZU, 2008.

67. Ovčak, Kos, Maja, Civilnopravna odgovornost zdravnikov, Ljubljana, Aletheia, 2017.

68. Pichler, Davorin, Obaviješteni pristanak u obrascima suglasnosti kojima se prihvaća preporučeni dijagnostički odnosno terapeutski postupak Kliničkog bolničkog centra Osijek i njihova usklađenost s propisima i međunarodnom praksom, Pravni vjesnik, god. 30, 1/2014., str. 89-114.

69. Pichler, Davorin, Privatno zdravstveno osiguranje u sustavu zdravstvenog osiguranja, Pravni fakultet Sveučilišta J. J. Strossmayer u Osijeku, 2014.

70. Plavšak, Nina, Juhart, Miha, Obligacijski zakonik s komentarjem, 4. knjiga, Ljubljana, GV Založba, 2004.

71. Polajner, Pavčnik, Ada, Obligacijski vidik razmerja med bolnikom in zdravnikom, Pravo in medicina, Ljubljana, Cankarjeva založba, 1998.

72. Radolović, Aldo, Pravo osobnosti u novom Zakonu o obveznim odnosima, Zbornik Pravnog fakulteta Sveučilišta u Rijeci, vol. 27., 1/2006, str. 129-170.

73. Radišić Jakov, Dužnost lekara da pacijenta obavesti o rizicima predložene medicinske mere i njegova odgovornost - poseban osvrt na praksu nemačkih i austrijskih sudova, Evropska revija za pravo osiguranja, 2/2012., str. 32-43.

74. Radišić, Jakov, Odgovornost zbog štete izazvane lekarskom greškom u lečenju i obaveštavanju pacijenta, Beograd, 2007.

75. Radišić, Jakov, Pravna priroda odgovornosti medicinskih poslenika i njihovog odnosa s pacijentima, Pravni život, 9-10/1992., str. 1759-1771.

76. Radišić, Jakov, Pristanak pacijenta na lečenje i odgovornost zbog lečenja bez punovažnog pristanka, Evropska revija za pravo osiguranja, 1/2012., str. 39-48.

77. Sjeničić, Ž. Marta, Pristanak pacijenta na meru lečenja, Zbornik Matice srpske za društvene nauke, 129/2009., str. 45-60.

78. Sorta Bilajac, Iva, Informirani pristanak - konceptualni, empirijski i normativni problemi Informed consent - conceptual, empirical and normative issues“, Medicina fluminensis, vol. 47, 1/2011, str. 37-47.

79. Spranger, Tade Matthias, Medical law in Germany, Kluwer Law Internacional, 2011.,

80. Szoeloesy, Paul, Tissot, Charles Robert, L'evaluation du dommage resultant de l'invalidité dans divers pays européens, Zürich, Schulthess, 1974. 
81. Stipković, Zlatan, Protupravnost kao pretpostavka odgovornosti za štetu, Zagreb, Pravni fakultet u Zagrebu, 1991.

82. Škavić, Josip, Zečević, Dušan, Komplikacija i greška - sudskomedicinski pristup u Građanskopravna odgovornost u medicini, Zagreb, HAZU, 2008.

83. Turković, Ksenija, Informirani pristanak i pravo na odbijanje tretmana u Republici Hrvatskoj, Zagreb, Hrestomatija hrvatskoga medicinskog prava, 2016., str. 551-566.

84. Virchow, Robert, Gesammelte Abhandlugen aus dem Gebiete der öffentlichen Medizin und der Seuchenlehre, 1. Band, Berlin, Hirschwald, 1879.

85. Vodinelić, V. Vladimir, Prava ličnosti - stare i nove dileme o nazivu i još ponečem, Liber amicorum Aldo Radolović, Zbornik radova, uredili: Z. Slakoper, M. Bukovac Puvača, G. Mihelčić, Rijeka, Sveučilište u Rijeci, Pravni fakultet, 2018., str. 259-300.

86. Vučemilo, Luka et al., Pristanak obaviještenog pacijenta s posebnim osvrtom na Hrvatsku, Liječnički vjesnik, 136/2014., str. 104-109. 


\section{Jakob Nakić* \\ Loris Belanić***}

Summary

\section{SIMILARITIES AND DIFFERENCES OF COMPENSATION FOR DAMAGES OF PATIENTS IN HEALTH INSTITUTION IN THE REPUBLIC OF SLOVENIA AND THE REPUBLIC OF CROATIA (THE TWO COURT CASES)}

The authors show the parallel legislation fees pecuniary and non-pecuniary damage caused to health facilities in the Republic of Slovenia and the Republic of Croatia. Further analysis of the man responsible for the damage caused to health facilities and on what basis. It also gives an overview of the legal relationship between patients and health care institutions, i.e. Doctors. In the case-law recently noticed an increase in claims for damages patients to health facilities because the paper presented at a court case, related to the damages caused in the health institution of the Republic of Slovenia and the Republic of Croatian and gives their analysis.

Keywords: medical institution; the right personality; property damage; immaterial Damage; patient; physician; health services.

Zussamenfassung

\section{ÄHNLICHKEITEN UND UNTERSCHIEDE ZWISCHEN DEM ERSATZ DES AN PATIENTEN VERURSACHTEN SCHADEN IN GESUNDHEITSEINRICHTUNGEN DER REPUBLIK SLOWENIEN UND REPUBLIK KROATIEN (DURCH DIE DARSTELLUNG ZWEI RECHTSSACHEN)}

Der Beitrag stellt die Gesetzesregulative des Ersatzes für den in Gesundheitseinrichtungen der Republik Slowenien und der Republik Kroatien entstandenen materiellen und immateriellen Schaden dar. Weiterhin analysiert der

* Jakob Nakić, Ph.D., Assistent Professor, Deputy of County Public Prosecutor in Rijeka, in retirement; jakob.nakic@yahoo.com.

** Loris Belanić, Ph.D., Associate Professor, University of Rijeka, Faculty of Law; lorisb@pravri. hr.

This paper is written under support of the University of Rijeka Research Project "Legal Aspects of Companies Restructuring and Transition Towards New Corporate Governance Culture" (uniri-drustv-18-43). 
Beitrag die Frage, wer für den in Gesundheitseinrichtungen entstandenen Schaden haftet und auf welchen Grund. Ebenfalls wird das Rechtsverhältnis zwischen den Patienten und der Gesundheitseinrichtung, bzw. der Ärzte dargestellt. Neulich kann man in der Rechtsprechung die Zunahme der Schadenersatzansprüche von Patienten gegenüber den Gesundheitseinrichtungen bemerken. Deshalb analysiert man in diesem Beitrag zwei Rechtssachen, welche mit dem Ersatz des in den Gesundheitseinrichtungen der Republik Slowenien und der Republik Kroatien entstandenen Schadens verbunden ist.

Schlüsselwörter: Gesundheitseinrichtung; Persönlichkeitsrecht; materieller Schaden; immaterieller Schaden; Arzt; medizinische Dienstleistung.

Riassunto

\section{SIMILARITÀ E DIVERSITÀ RELATIVE AL RISARCIMENTO DEL DANNO DEI PAZIENTI NELLA STRUTTURA SANITARIA NELLA REPUBBLICA DI SLOVENIA E NELLA REPUBBLICA DI CROAZIA (ATTRAVERSO L'ANALISI DI DUE CASI GIURISPRUDENZIALI)}

Gli autori nel lavoro illustrano parallelamente la normativa giuridica del danno patrimoniale e non patrimoniale sorto nelle strutture sanitarie nella Repubblica di Slovenia e nella Repubblica di Croazia. Successivamente disaminano chi risponda dei danni cagionati nelle strutture sanitarie e sulla base di quali presupposti. Altresì riflettono sul rapporto giuridico tra i pazienti e le strutture sanitarie, cioè i medici. Nella giurisprudenza in tempi recenti si osserva un aumento di richieste da parte dei pazienti di risarcimento del danno nei confronti delle strutture sanitarie; perciò nel lavoro viene illustrato un caso giurisprudenziale per ciascun ordinamento (sloveno e croato) relativo al risarcimento del danno sorto in una struttura sanitaria, procedendo all'uopo alla loro analisi.

Parole chiave: struttura sanitaria; diritto della personalità; danno patrimoniale; danno non patrimoniale; paziente; medico; prestazione sanitaria. 
